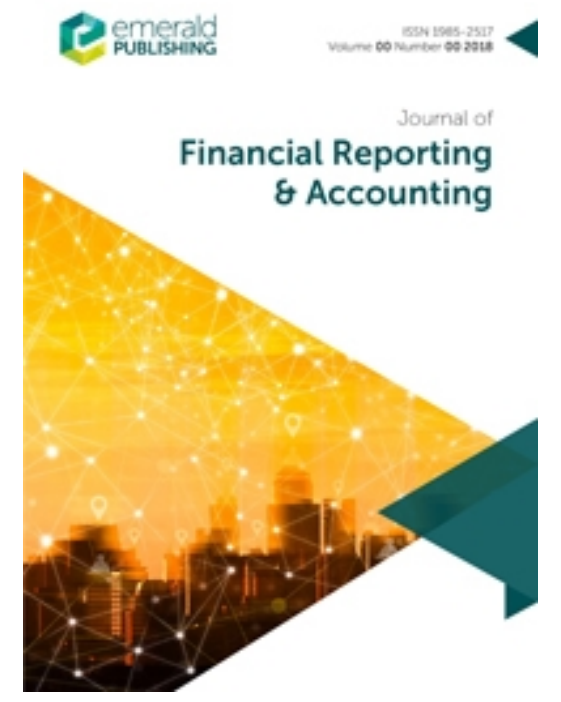

\title{
Agency and institutional related factors and the heterogeneity of sustainability and integrated report information disclosures in Kenya
}

\begin{tabular}{|r|l|}
\hline Journal: & Journal of Financial Reporting and Accounting \\
\hline Manuscript ID & JFRA-10-2020-0305.R2 \\
\hline Manuscript Type: & Research Paper \\
\hline Keywords: & $\begin{array}{l}\text { Corporate Reporting, sustainability reporting, integrated reporting, } \\
\text { agency theory, Institutional theory }\end{array}$ \\
\hline \multicolumn{2}{|l}{} \\
\hline
\end{tabular}




\section{Introduction}

Over the last few decades, there have been increasing attempts by international bodies such as the International Accounting Standards Board (IASB), the Global Reporting Initiative (GRI) and the International Integrated Reporting Committee (IIRC) to improve the quality of corporate reporting (see IASB, 2018; GRI, 2020; IIRC, 2020). These attempts are underpinned by the rationale that enhanced disclosure of information reduces the information asymmetry between managers and stakeholders, including shareholders (Healy and Palepu, 2001; Karamanou and Vafeas, 2005). The 2007-2009 global financial crisis (GFC) particularly demonstrated the importance of enhanced transparency by companies, not only in terms of financial information, but also nonfinancial information.

Whereas the disclosure of financial information has a very long history, the impetus for enhanced nonfinancial information reporting developed from the recent and increasing public attention on the socially responsible behaviour of corporations and intensified in the aftermath of the GFC (Adams, 2002; de Villiers et al., 2014; Barth et al., 2017; Mathuva et al., 2019). In response, newer reporting frameworks to supplement financial information have emerged. In particular, among others, the GRI has made substantial attempts to promote and improve sustainability reporting (SR) by developing guidance for use by companies. ${ }^{1}$ Extant evidence demonstrates that the uptake of the GRI guidelines has been widespread across the world, including in the developing countries, with companies either publishing standalone sustainability reports or including sustainability information as part of the annual reports (see Prado-Lorenzo et al., 2009; Higgins et al., 2015; Barkemeyer et al., 2015).

Although the GRI has been an important and welcome development, companies' sustainability reports have been criticized as being disconnected from the financial reports as well as failing to relate sustainability initiatives to corporate strategy (Jensen and Berg, 2012). This has been argued that it creates information gaps and confusion for investors and other stakeholders in their attempt to understand the connection between strategy, financial performance, and social and environmental impacts of the company (Jensen and Berg, 2012; IIRC, 2013; KPMG, 2017). In an attempt to address this problem, the IIRC developed an integrated reporting framework to guide companies on how to present, in a single integrated

\footnotetext{
${ }^{1}$ GRI describes a sustainability report as providing 'a balanced and reasonable representation of the sustainability performance of the reporting organisation including both positive and negative contributions' to sustainability concerns (GRI, 2011, p. 3).
} 
report (IR), the financial and sustainability information in a way that provides better understanding of how a company creates value (IIRC, 2013; de Villiers et al., 2014; KPMG, 2017). ${ }^{2}$ To-date, South Africa is the only country to mandate IR for listed companies (Barth et al., 2017), but IR has also gained traction, with the framework or aspects of it being embraced voluntarily by companies in over 70 other countries that include both developed countries (e.g., UK, Netherlands, Singapore, Japan, Australia) (see de Villiers et al., 2014; Le Roux and Pretorius, 2019) and developing countries (e.g., Kenya, Uganda, Mauritius, Nigeria, Zimbabwe) (see Bananuka et al., 2018; Modack, 2018; Injeni et al., 2019).

Despite the usefulness and growing adoption of these newer reporting frameworks, little is known about the quality of sustainability reporting and integrated reporting practices of companies, particularly in the context of developing countries (Frías-Aceituno et al., 2014; Venter et al., 2017; Barth et al., 2017). In this regard, Rinaldi et al. (2018) call for more academic research to understand the drivers, the processes and the consequences of reporting. Consequently, in this paper, we attempt to contribute to the literature by examining the extent of disclosure of both sustainability information and integrated report information by companies listed on the Nairobi Securities Exchange (NSE) in Kenya. In addition, the Kenyan context motivates an exploration of the agency-related and institutional-related factors that influence each type of disclosure. More specifically, the agency-related factors examined include corporate governance structures in place. The institutional-level drivers include regulatory changes, reporting excellence awards and the sector in which the company operates in.

Examining the two disclosure types (i.e., SR and IR) is particularly important because both reporting frameworks are largely voluntary. We however note increasing efforts by regulatory authorities and professional accountancy bodies to encourage the adoption of the two frameworks in various jurisdictions. As far as the two reporting frameworks are concerned, managers have the discretion whether to adopt or not. More importantly, the managers can determine what and how much information to disclose in their annual reports with regard to the two frameworks. ${ }^{3}$ In this context, investigating the extent as well as the

\footnotetext{
${ }^{2}$ IR is 'a concise communication about how an organization's strategy, governance, performance and prospects, in the context of its external environment, lead to the creation of value over the short, medium and long term' (IIRC, 2013, p. 7).

${ }^{3}$ The Companies Act (2015) requires companies to report information about environmental matters, the employees of the company and social and community issues but does not provide the details of the information to disclose. In addition, the regulatory authorities and the professional body recommend the adoption or at least
} 
drivers of the disclosures has substantial implications for regulators, business practice, investors and academic researchers.

Kenya is an interesting context to investigate for a number of reasons. First, although there are several studies across the world analysing the drivers of SR (Khasharmeh and Suwaidan, 2010; Dilling, 2010; Rouf and Hossain, 2011; Rashid, 2018) and IR (Ahmed Haji and Hossain, 2016; Steyn, 2014; Adhariani and de Villiers, 2019), prior literature suggests that sustainability practices and reporting vary with a country's institutional factors (see Smith, 2005). Modack (2018) and Bananuka et al. (2019) point to the weak legal systems, the high cost of producing reports, little expertise, and lack of resources as impediments to sustainability and integrated reporting in countries such as Kenya (see also Modack, 2018; Bananuka et al., 2019). Indeed, Bova and Pereira (2012) observe that Kenya is a low enforcement country, and this is alluded to by Mathuva and Chong (2018).

Second, in common with other developing countries (including in Africa), Kenya has made efforts to improve corporate reporting (World Bank, 2010; Waweru et al., 2019). More recently, the professional accountancy body, the Institute of Certified Public Accountants of Kenya (ICPAK), the Capital Markets Authority (CMA) and the NSE have encouraged listed companies to embrace the SR and IR frameworks and engage in high quality sustainability reporting and integrated reporting (Injeni et al., 2019). In this context, it may be argued that Kenya is in transition to these new reporting frameworks and therefore it is apposite to investigate how companies are responding to these initiatives.

Third, as a country, Kenya is among the pioneer members of the African Integrated Reporting Council (AIRC) (IFAC, 2017) which was formed to support integrated reporting in African countries. In line with this, the key stakeholders in Kenya, being the ICPAK, the CMA, and the NSE, have been making individual and joint efforts to improve the quality of disclosure. For instance, the creation of the Financial Reporting Excellence (FiRe) award which incorporate sustainability, integrated and governance information (Mathuva et al., 2017; Injeni et al., 2019). Finally, regulators in Kenya have made substantial drives to improve reporting. For instance, the CMA adopted and implemented a Code of Corporate Governance for issuers securities to the public in 2015 (Republic of Kenya, 2015b) to support effective governance of companies, including enhancing the quality of corporate reporting. The Code

publish information about integrated reporting. This leaves individual companies with considerable discretion on what to disclose. 
requires the board, the audit committee, and large shareholders to play a visible role in improving transparency in listed companies. In addition, Kenya revised its Companies Act (2015), with one of the aims being to improve levels of transparency by companies. In this case, the Act requires companies to report, not only financial information, but also to disclose information about environmental matters, the employees of the company and social and community issues (Government of Kenya, 2015).

Taken all together, examining the disclosure of sustainability and integrated report information in Kenya can help professional and regulatory bodies review the progress made to date. This is useful in informing policy decisions on enhancing the quality of corporate reporting and aiding to attract foreign investment through the securities exchange (Mangena and Tauringana, 2007). We analyse the sustainability and integrated report disclosures using self-developed disclosure scores of 53 companies listed on the NSE during the period 2010 through 2018. We find that companies appear to engage more in integrated report information disclosure than they do with sustainability information disclosure. Moreover, we find that both disclosure types have increased over time. We also find that level of disclosure is a function of agency-related factors, specifically, board gender diversity, audit committee independence, the presence of foreign ownership and block ownership. In addition, there is evidence suggesting that the increase in the disclosures has been influenced by institutionalrelated factors. More specifically, we establish that the promotional efforts of regulatory bodies and professional bodies in Kenya through the use of reporting excellence awards influence the disclosure of information, especially, IR information disclosures.

Our paper contributes to literature in several ways. First, whereas most studies examine either sustainability reports (e.g., Khasharmeh and Suwaidan, 2010; Dilling, 2010; Rouf and Hossain, 2011; Rashid, 2018) or integrated reports (Ahmed Haji and Hossain, 2016; Steyn, 2014; Adhariani and de Villiers, 2019), we investigate both at the same time allowing us to compare the extent and drivers of the two disclosures. This approach allows us to unearth the salient factors that explain the heterogeneity in disclosure as firms opt to adopt alternative reporting approaches (Nicholls, 2020). Our findings that the disclosure types are influenced by similar factors are interesting and inform future research. Second, we extend prior studies examining sustainability reporting in Kenya (e.g., Barako and Brown, 2008; Mathuva et al., 2018). Whereas these studies examined the effects of factors such as company size, industry, and profitability, we extend the analyses by analysing the role of agency-related factors (i.e., 
corporate governance structures) and institutional-related factors (i.e., regulatory changes, reporting excellence awards and sector). As far as we are aware, institutional-related factors that we examine, have not been analysed in prior literature and therefore this is an innovation. By examining the institutional-related factors, particularly the regulatory changes and reporting excellence awards, we contribute by showing the real effects of mandatory reporting as the promotional efforts of both regulatory and professional bodies in Kenya. The findings showing that the reporting excellence awards have positive effects are a contribution to this effect. Third, extant studies have tended to examine the adoption of integrated reporting and its drivers (Rinaldi et al., 2018; Modack, 2018). We differ from these studies by analysing the disclosure of integrated reporting information and the factors influencing such disclosure in an African country that is transitioning to new reporting frameworks. Finally, our study informs policy discussions and company practice of sustainability and integrated reporting in Kenya.

The rest of the paper is arranged as follows. Section 2 discusses the evolution of corporate reporting practices in Kenya, with particular focus on the transition from IFRS to the newer reporting frameworks. Section 3 presents the literature review and develop the hypotheses. In section 4, we discuss the research methods while section 5 presents and discusses the results. Finally, section 6 concludes the paper and provides directions for future research.

\section{The evolution of corporate reporting practices in Kenya}

The regulation of corporate reporting in Kenya is underpinned by the Companies Act 2015 which specifies the basic requirements for reporting. In relation to financial information, the Act requires listed companies to comply with International Financial Reporting Standards (IFRS) as adopted by ICPAK (Republic of Kenya, 2015a, Par. 638 (3, a)). The Act also requires companies to prepare a business review (Republic of Kenya, 2015a; Modack, 2018). In the business review, companies are expected to disclose information about their business, a description of the principal risks and uncertainties facing the company, a balanced and comprehensive analysis of business growth, performance and position, the main trends and factors likely to affect the future development, performance and position. In addition, the Act also calls for the disclosure of nonfinancial information about environmental matters, the employees of the company and social and community issues and an analysis using financial key performance indicators (Republic of Kenya, 2015a). However, the Act does not provide 
the details of the information companies should disclose, thus leaving the discretion the management of the companies.

The Companies Act requirements are complemented by ICPAK which has the responsibility to develop and implement accounting standards (Barako, 2007). According to the report on the observance of standards and codes, the ICPAK adopted the International Financial Reporting Standards (IFRS) in 1998, and taking effect from $1^{\text {st }}$ January 1999 (World Bank, 2010). These standards are enforceable as the CMA (2002), the Companies Act of 2015 and the tax authority require firms to produce IFRS-compliant financial statements (World Bank, 2010). According to the World Bank (2010), IFRS compliance levels in Kenya are high, although not fully compliant due to implementation challenges such as the reluctance by top management to fully comply as well as the weak enforcement of the standards (Bova and Pereira, 2012). To encourage firms to comply with the accounting standards, ICPAK makes use of the financial reporting excellence awards that were initiated in 1986 (McFie, 2010). These awards are presented to companies judged as publishing the best financial reports that are consistent with existing accounting standards.

In addition, and in line with the rest of the world, the regulatory authorities and the professional accountancy body have emphasized the adoption newer reporting frameworks. In particular, companies are encouraged to publish sustainability information in line with the Global Reporting Initiative (GRI) and to adopt integrated reporting as recommended by the IIRC. In an attempt to encourage adoption of these new reporting frameworks, the reporting of nonfinancial information, in particular environmental, social and governance information (i.e., sustainability information), was added to the reporting excellence awards (McFie, 2010; Mathuva, 2018). In this context, demonstrating its commitment to both financial and nonfinancial reporting, ICPAK highlights that the objectives of the financial reporting excellence awards are to promote financial reporting excellence, foster sound CG practices and enhance corporate social and environmental reporting (Mathuva, 2018). Additional themes on IR were incorporated in the reporting excellence checklist since 2016 to encourage disclosure of highquality information. While recommending adoption of IR, the authorities recognise that full adoption will be a process, and therefore encourage companies to at least publish aspects of IR information as they transition towards IR full adoption (Injeni et al., 2019). This has led to listed companies making more disclosures in their annual reports, but within the context of management discussions and analysis (Mathuva, 2018; Injeni et al., 2019). However, the extent and drivers of disclosures in these new reporting frameworks in Kenya are unclear. 


\section{Literature review and hypotheses}

Our paper examines the drivers of disclosure of sustainability report and integrated report information by listed companies in Kenya. A growing body of studies examine the determinants of both sustainability report disclosures (e.g., Gao et al., 2005; Barako and Brown, 2008; Darus et al., 2009; Michelon and Parbonetti, 2012; Garcia et al., 2017; Kuzey and Uyar, 2017; Al-Shaer and Zaman, 2018; Bravo and Reguera-Alvarado, 2019) and integrated report disclosures (e.g., Frias-Aceituno et al., 2014; Vitolla et al., 2019; Manes-Rossi et al., 2020; Songini et al., 2021; Raimo et al., 2021; 2021). These studies show that the structure of boards, in particular board representation and diversity, and ownership structures are important determinants of sustainability information disclosure (e.g., Barako and Brown, 2008; Post et al., 2011; Al-Shaer and Zaman, 2018; Bravo and Reguera-Alvarado, 2019) and integrated report information disclosure (e.g., Frias-Aceituno et al., 2014; Manes-Rossi et al., 2020; Raimo et al., 2020; Nicolo et al., 2020; Raimo et al., 2021; Songini et al., 2021). Others have shown that industry sectors and social and environmental sensitivity are important influences of decisions to disclose sustainability and integrated report disclosures (e.g., FriasAceituno et al., 2014; Kuzey and Uyar, 2017; Nicolo et al., 2020). The impact of institutional factors, such as the legal system and culture, and political systems, on sustainability and integrated report disclosures has also been examined (e.g., Jensen and Berg, 2012; Modack, 2018; Girella et al., 2019; Bananuka et al., 2019). We extend these prior studies by focusing on the context of Kenya, a developing country that encourages the adoption of these new forms of corporate reporting.

The disclosure literature points that disclosure has both benefits and costs. Elliot and Jacobson (1994) and Healy and Palepu (2001) summarize these benefits and costs. The benefits include the correction of undervaluation of shares and reduction of information asymmetry leading to liquidity improvements and lower cost of capital. In relation to costs, the existence of agency problems may cause investors and other stakeholders to view disclosures as non-credible leading to a reduction in the company's share prices or being perceived as brainwashing. The concerns about credibility of disclosures can be more pronounced for sustainability and integrated report information because they are unaudited. The other costs are proprietary in nature, in particular, revealing competitive information, thereby reducing shareholder value, and costs related to preparation of the reports (Healy and Palepu, 2001). If the benefits outweigh the costs, companies are more likely to have 
incentives for greater disclosure. Such disclosure incentives would differ among companies for several reasons.

In the extant literature, the decisions for disclosure have been explained using several theories, including the agency theory, stakeholder theory, and institutional theory (see Healy and Palepu, 2001; Waweru et al., 2019). We draw from these three theories in examining the motivations for disclosure of sustainability and integrated report information. Building on these theories, we suggest that the motivations for listed companies in Kenya to disclose greater sustainability report and integrated report information are a function of agencyrelated factors and institutional-related factors. We discuss and develop hypotheses in the following sections. Our hypotheses on agency-related factors draw from the agency and stakeholder theories and those on institutional-related factors are underpinned by the institutional theory.

\subsection{Agency-related factors and, sustainability and integrated information}

Both the agency theory (Jensen and Meckling, 1976) and stakeholder theory (Freeman, 1984) point to the fact that enhanced disclosure of information is a way of minimising potential agency conflicts between the management of the company and stakeholders. The key and contentious difference between the two theories relates to where the accountability of the company lies. Whereas the agency theory argues that accountability is to shareholders, the stakeholder theory argues that such accountability is to a wide range of stakeholders. Stakeholders, as defined in Freeman (1984), include anyone or any group, that is affected by or affects the achievement of a company's objectives. These stakeholders include, among others, shareholders (the emphasis of agency theory), creditors, employees, local communities and the public in general. According to Mitchell et al. (1997) and Smith et al. (2005), the long-term survival of companies depends on the effectiveness of their dialogue with all their key stakeholders, not only shareholders. Thus, we suggest that given the nature of sustainability as well as integrated report information, both agency theory and stakeholder theory can be applied to explain the disclosure practices in our context. On the one hand, from an agency theory viewpoint, shareholders are interested in understanding how investments in sustainability initiatives contribute to long-term value of the company, and their own wealth (e.g., Girella et al., 2019; Raimo et al., 2021). On the other hand, taking a stakeholder viewpoint, stakeholders such as local communities and the public in general would be 
interested in understanding how companies create value within the context of the social and environmental concerns (e.g., Gray et al., 1995; Adams, 2002).

In this context, both shareholders and other stakeholders would be interested in enhanced disclosure of both sustainability and integrated report information. The sustainability information would aid their understanding of the impacts of companies on the social and environment, including the investments they are making to reduce any adverse impact. The integrated report information would provide understanding of how the investments in sustainability are related to the financial performance of the company, and thus helping to clarify that the company is neither just in legitimising their operations (Gray et al., 1995; Adams, 2002) nor are managers just extracting wealth from shareholders (Mangena and Pike, 2005). Following Gray et al. (1995), we argue that greater disclosure of both sustainability and integrated report information by listed companies in Kenya is an attempt to engage in dialogue with all stakeholders by reducing information asymmetries between the company and the stakeholders. In particular, we consider the disclosures as a way by which companies demonstrate to both shareholders and other stakeholders that their performance is closely connected with their impacts on the social and environment within which they operate.

In line with established literature (e.g., Mangena and Pike, 2005; Karamanou and Vafeas, 2005; Mangena and Tauringana, 2007; Barako and Brown, 2008; Frias-Aceituno et al., 2014; Waweru et al., 2019), we identify several drivers that may have impacts on the relationship between the company and its stakeholders and develop appropriate hypotheses. Jensen (1993), Yermack (1996), Michelon and Parbonetti (2012) argue that corporate governance structures play an important role in minimising the information asymmetries between the company and the stakeholders. In this context, strong corporate governance structures are essential in promoting better dialogue between the company and stakeholders via the monitoring of the corporate reporting processes and ensuring transparency. Karamanou and Vafeas (2005) and Mangena and Pike (2005) identify board and ownership structures as critical in minimising agency problems between management and stakeholders.

In relationship to board structures, in this paper, we consider board independence, board diversity and audit committee as influencing the disclosure of sustainability and integrated reporting information by listed companies in Kenya. In Kenya, the corporate governance code (CMA, 2002) emphasises the role of the board of directors and its audit committee in maintaining an effective system to ensure the provision of information to shareholders, 
stakeholders and general public. In the literature, the conventional wisdom is that independent (outside) board members are better placed to improve the quality of disclosures because they are not conflicted and have incentives to inform stakeholders about the operations of the company (Fama and Jensen, 1983; Jensen, 1993; Waweru et al., 2019). Johnson and Greening (1999) and Michelon and Parbonetti (2012) suggest that independent boards are more likely to have strong stakeholder-oriented incentives and these allow them to encompass the multiple needs of stakeholders. This implies that engagement with stakeholders is likely stronger and more effective in companies with greater board independence. As a company's disclosure policy is determined by the board of directors, we expect board independence to influence disclosure policy towards enhanced disclosure of both sustainability and integrated report information as a response to stakeholder information needs. Prior literature provides evidence consistent with independent directors leading to greater disclosure in general (e.g., Barako et al., 2006; Waweru et al., 2019), sustainability information (e.g., Post et al., 2011; Liao et al., 2015; Al-Shaer and Zaman, 2016) and integrated reporting (e.g., Vitolla et al., 2019; Raimo et al., 2021).

In addition to board independence, the role of women on boards has been emphasized in the literature and policy considerations. According to Adams and Ferreira (2009) and Post et al. (2011), women directors enhance board independence and are more likely to challenge groupthink decision-making tendencies leading to better outcomes. Abdullah and Valentine (2009) suggest that they are also likely more stakeholder-oriented, with greater concern for ethical practices and socially responsible actions. Gul et al. (2013) and Al-Shaer and Zaman (2016) argue that women have the desire to be more open in building relationships and likely to have incentives to engage with stakeholders better than men. Essentially, this implies that they are more likely to promote greater disclosure of both sustainability information and integrated report information as a way of building stronger relationships with all stakeholders. Empirically, evidence suggests that gender diversity is associated with transparent reporting (e.g., Krishnan and Parsons, 2008), sustainability reporting (Barako and Brown, 2008; Prado-Lorenzo and Garcia-Sanchez, 2010; Post et al., 2011; Al-Shaer and Zaman, 2016) and integrated reporting (Frias-Aceituno et al., 2013; Gerwanski et al., 2019; Vitolla et al., 2019; Songini et al., 2021). Thus, we hypothesise the following in terms of board independence and gender diversity:

$H_{1 a}:$ Board independence is positively associated with SR information disclosures 
$H_{1 b}$ : Board gender diversity is positively associated with SR information disclosures

$H_{1 c}:$ Board independence is positively associated with IR information disclosures

$H_{1 d}:$ Board gender diversity is positively associated with IR information disclosures

Finally, the audit committee has for decades been promoted as critical for ensuring the quality of financial reporting (see Karamanou and Vafeas, 2005; Mangena and Pike, 2005; Mangena and Chamisa, 2008; Li et al., 2012; Waweru et al., 2019; Samaha et al., 2012) and more recently its remit has extended to sustainability reporting (KPMG, 2017; Al-Shaer and Zaman, 2018; Bravo and Reguera-Alvarado, 2019) and integrated reporting (Raimo et al., 2021). Both Mangena and Pike (2005) and Karamanou and Vafeas (2005) suggest that its effects on reporting is a function of its independence and show that independence is related positively to voluntary disclosure. Other studies provide similar evidence relating to intellectual capital disclosure (Li et al., 2012) and internet reporting disclosure (Waweru et al., 2019). With specific focus on sustainability information, Arif et al. (2020) find that audit committee independence is associated with disclosure of sustainability information. Raimo et al. (2021) show that audit committee independence is positively associated with integrated reporting quality. Overall, these findings demonstrate that an audit committee whose members are independent enhance monitoring and consequently the quality of reports. Following the above discussion, we predict the following:

$H_{2 a}$ : Audit committee independence is positively associated with SR information disclosures $H_{2 b}$ : Audit committee independence is positively associated IR information disclosures

With regard to ownership structure, Jensen and Meckling (1976) argue that companies with diffuse ownership will disclose more information in their reports to satisfy the information demands of the diverse shareholders. Similarly, Martson and Polei (2004) also suggest that companies with less concentrated shareholding (shareholders having fewer blocks of shares) are expected to disclose more information. Reverte (2009) supports this view, arguing, that investors with large equity shares in a company have direct access to information within the company and therefore do not demand companies to publicly increase their disclosure. Mangena and Pike (2005) and Karamanou and Vafeas (2005) find no significant between ownership concentration (referred to as block ownership). However, some studies provide evidence inconsistent with agency theory view that diluted ownership, rather than concentrated ownership enhances disclosure. These studies have shown a positive 
association between ownership structure and social disclosures (e.g., Saleh et al., 2010; Ntim and Soobaroyen, 2013), corporate social responsibility disclosure (e.g., Mohd Ghazali, 2007; Darus et al., 2009) and voluntary disclosure in general (e.g., Barako et al. 2006; Waweru et al., 2019).

In relation to integrated reporting, Raimo et al. (2020) find a negative relationship between integrated reporting and ownership concentration, while Manes-Rossi et al. (2020) find a positive relationship between government ownership and the level integrated report disclosures. Both Barako et al. (2006) and Waweru et al. (2019) find, in the context of Kenya, that the effects of ownership concentration (block ownership) on voluntary disclosure were mainly due to foreign ownership, rather than local or domestic ownership. This implies that the relationship between ownership concentration (block ownership) and sustainability disclosures as well as integrated report disclosures may be moderated by the presence of foreign ownership in the firm. This is consistent with prior literature suggesting that foreign investors would demand greater public disclosures to reduce the information gathering costs associated with investing on foreign stock exchanges (Young and Guenther, 2003; Ahearne et al., 2004). Thus:

$H_{3 a}$ : Block ownership is positively associated with SR information disclosures

$H_{3 b}$ : The presence of foreign ownership in the firm moderates the relation between block ownership and SR information disclosures

$H_{3 c}$ : Block ownership is positively associated with IR information disclosures

$H_{3 d}$ : The presence of foreign ownership in the firm moderates the relation between block ownership and IR information disclosures

\subsection{Institutional related factors and, sustainability and integrated information}

In relation to institutional drivers of disclosure, the institutional theory viewpoint is that national pressure and incentives would impact companies' motivation, not only to adopt a new reporting framework, but also to engage meaningfully with the requirements of the new framework (DiMaggio and Powell, 1983; Jackson and Apostolakou, 2010; Jensen and Berg, 2012). In particular, the institutional context exerts pressures on companies to subscribe to certain disclosure approaches (Jackson and Apostolakou, 2010; Jensen and Berg, 2012). These pressures derived from regulation (coercive pressures), industry peers (mimetic pressures), political forces, culture, or professional bodies (normative pressures). In the context of Kenya, the requirement of the Companies Act (2015) for listed companies to report not only financial 
information, but also nonfinancial information about environmental matters, the employees of the company and social and community issues, can be viewed as a coercive force for disclosure. Whereas prior to 2015, the reporting of this information was voluntary, it became a legal requirement for all listed companies, and thus it would be expected that disclosure would be greater following the introduction of requirements.

As the Companies Act requirements do not cover IR, we suggest that integrated reporting information disclosures are likely to be influenced by the promotional efforts of the regulatory and professional bodies (normative forces). In particular, the CMA, NSE and ICPAK, in 2016, expanded the reporting excellence awards from only financial reporting and sustainability reporting to integrated reporting to incentivise companies to improve the quality of information (Mathuva, 2018; Injeni et al., 2019). Both Mathuva (2018) and Injeni et al. (2019) suggest that listed companies respond to these awards and making more disclosures in their annual reports, particularly within the context of management discussions and analysis.

To the extent that companies are influenced by the reporting excellence awards (Mathuva, 2018; Injeni et al., 2019), we expect enhanced disclosure of integrated reporting information following their inclusion into the reporting excellence awards. Moreover, the mere fact that regulators such as CMA, ICPAK and NSE promote IR information disclosures, might compel companies to respond and comply, either to avoid being mandated to do so by future regulation (as is the case for sustainability reporting) or just in anticipation of regulations requiring compliance in the future. Our argument is consistent with Gray and Roberts (1989). These authors found that managers are motivated by proposals or recommendations of regulatory and professional bodies in their decision to voluntarily disclose information because of the anticipation of potential subsequent reporting requirements. Hence, we predict the following:

$H_{4 a}$ : The level of SR information disclosures is influenced by the introduction of sustainability reporting requirements in the Companies Act 2015.

$H_{4 b}$ : The level of IR information disclosures is influenced by introduction of integrated reporting into the reporting excellence awards.

Finally, the sector in which a company operates can act as an important driver for its motivation to adopt a reporting framework and/or to enhance disclosure as required by that reporting framework. We present two arguments for this. First, from the perspective of the institutional theory, companies would copy or mimic disclosure practices of their industry 
peers, to the extent that those peers' disclosures are viewed as best practice (DiMaggio and Powell, 1983; Jackson and Apostolakou, 2010; Jensen and Berg, 2012). For instance, Dye and Sridhar (1985) demonstrate that voluntary disclosure by some companies provokes other companies in the same industry to make similar or related disclosures. Barako et al. (2006) find, in the context of Kenya, that the sector in which the company operates is associated with the level of voluntary disclosure.

Second, some industries, due to the nature of their operations, are in general under pressure to report more information to demonstrate their legitimacy in the eyes of stakeholders. For instance, companies in the manufacturing, mining, construction and energy sectors generally face greater demands, particularly from environmental pressure groups, the media and politicians, for social and environmental information given the impacts they have on society and the environment (Adams, 2002; Gao et al.,2005; Dagiliene and Nedzinskienen, 2018). Such public attention or scrutiny may force companies to respond with enhanced disclosure to demonstrate their legitimacy and wade off bad public attention. This can be achieved by increasing the level of sustainability information as well as publishing a highquality integrated report information to demonstrate how the company's strategy and performance clearly relate to the impacts of the company's operations.

Empirically, there is evidence to show that companies that operate in such sectors as manufacturing, construction, mining and energy (often referred to as sensitive sectors) provide greater disclosures than other sectors as an attempt to reduce scrutiny or criticisms (e.g., Dennis et al., 2015; Botha and Middelberg, 2016; Garcia et al., 2017). With specific focus on IR information disclosures, Marrone and Oliva (2019) find that companies operating in highly polluting sectors report information that is closely aligned with the integrated reporting framework. Nicolo et al. (2021) examine state-owned enterprises and find that compliance with integrated framework requirements was greater for companies with greater social and environmental impacts. These findings suggest that companies in sensitive sectors are likely provide better quality integrated information than others.

Following the above arguments, we suggest that companies in sensitive sectors would not only independently enhance their disclosures, but they are also more likely to mimic the best practice of the other sensitive sector companies to avoid being singled out by criticisms. Thus: 
$H_{5 a}$ : Companies operating in sensitive sectors (manufacturing, construction and energy sectors) are more likely to provide greater level of SR information disclosures.

$H_{5 b}$ : Companies operating in sensitive sectors (manufacturing, construction and energy sectors) are more likely to provide greater level of IR information disclosures.

\section{Methodology}

\subsection{Sample of the study}

Our sample is drawn from listed companies on the Nairobi Securities Exchange (NSE). The study period begins in 2010 through to 2018 to allow for an examination of how sustainability and integrated report information has evolved over time, since the time the IIRC was launched (IIRC, 2010). This is also the year when the GRI signed an MOU with the UN Global Compact (UNGC) to integrate the UNGC's 10 principles and then included the issues in the SR guidelines (GRI, 2019). As of 31 December 2019, there were 66 listed companies on the NSE. We eliminated four and nine companies that were suspended from trading and that had incomplete data, respectively. The resultant sample is as detailed in Table 1.

\section{[Insert Table 1 about here]}

\subsection{Empirical strategy and model}

\subsubsection{Development and scoring of corporate reporting indices}

To construct the disclosure score, and consistent with earlier works (e.g., Marston and Shrives, 1991; Mangena and Pike, 2005; Mangena and Tauringana, 2007), we employ disclosure indices: SR Score and IR Score. We first develop a checklist based on the guidelines issued in the GRI G4 framework (GRI, 2013) (for SR Score) and the IIRC's IR framework (IIRC, 2013) (for IR Score). The total number of items generated from this exercise is 63 disclosure items for the SR score and 47 disclosure items in the IR Score. The checklists for the two indices are presented in Appendix 1.

We then collect annual reports of the listed companies and, using the checklists, score the annual reports using content analysis. In our scoring, we use an unweighted scoring approach, 
where for each item, a company is awarded a " 1 " if the disclosure item is present and " 0 " if it is not (Mangena and Pike, 2005; Barako et al., 2006; Mathuva et al., 2017). The rationale for using unweighted indices is twofold. First, it avoids the subjectivity associated with attaching weights to disclosure items (Bravo et al., 2009). Second, Mangena and Pike (2005) show that the use of weighted or unweighted scores in understanding the drivers of disclosure leads to the similar results. ${ }^{4}$

The total disclosure score was computed by dividing the actual disclosure score (all the ones) by the total possible disclosure score (63 or 47 as relevant) for each company. The formula used is as follows:

$$
\text { Discl_Score }_{i t}=\frac{\sum_{t=1}^{n} \text { Actual Disclosure Items }}{\sum_{t=1}^{n} \text { Total Disclosure Items }}
$$

Discl_Score can be either SR Score or IR Score as relevant. The scoring process was undertaken independently by two well-trained assistants. The first author then randomly selected an average of 20 annual reports in each year and independently scored these reports following the same process as the two assistants. To confirm the reliability of the scores in each disclosure index, a Cronbach's scale reliability coefficient was then calculated. In all cases, the Cronbach's alpha is greater than 0.90 implying a higher degree of inter-item reliability of the indices (Taber, 2018). ${ }^{5}$

\subsubsection{Empirical model}

To test the hypotheses, we employ the following main models.

$$
\begin{aligned}
& \text { SR Score }_{t t}=\beta_{0}+\beta_{1} \text { Bind }_{t}+\beta_{2} \text { Gender }_{t}+\beta_{3} \text { ACInd }_{t}+\beta_{4} \text { Block }_{t}+\beta_{5} \text { DForOwn }_{t}
\end{aligned}
$$

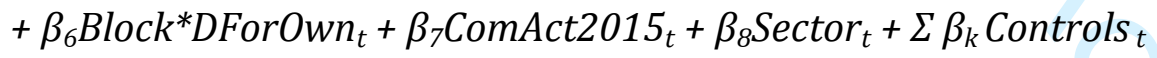

$$
\begin{aligned}
& \text { IR Score }_{t t}=\beta_{0}+\beta_{1} \text { Bind }_{t}+\beta_{2} \text { Gender }_{t}+\beta_{3} \text { ACInd }_{t}+\beta_{4} \text { Block }_{t}+\beta_{5} \text { DForOwn }_{t}
\end{aligned}
$$

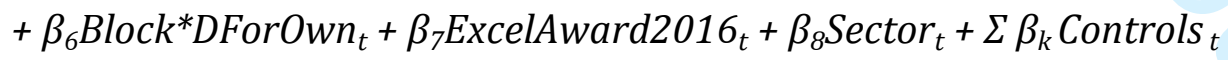

\footnotetext{
${ }^{4}$ Mangena and Pike (2005) use both unweighted scores and weighted scores based on the ratings of investment analy\#sts.

${ }^{5}$ We also carried out a simple correlation of the scores from the three scorers and find that the scores among the scorers were very highly correlated.
} 
All variables are as defined in Table 2.

[Insert Table 2 about here]

We control for other variables that are known to impact the decision to disclose information. In particular, we include company size (natural log of total assets) (Frias-Aceituno et al., 2014; Garcia-Sanchez et al., 2013; Marrone and Oliva, 2020; Nicolo et al., 2021), profitability (Return on assets) (Frias-Aceituno et al., 2013, 2014; Marrone and Oliva, 2020; Manes-Rossi et al., 2020) and leverage (Mangena and Pike, 2005; Mangena and Tauringana, 2007; Waweru et al., 2019). We also control for the formal adoption of integrated reporting (IR Adoption) using a dummy variable 1 if formally adopted IR, and 0 otherwise. The rationale for this variable is to capture the fact that those companies that have formally adopted may provide greater disclosures than those that have not.

We run the analyses by employing panel data models as our dataset is both crosssectional and time-series. In making the decision as to which panel model to use, we considered the fixed effects model, the random effects model and the generalized estimation equations (GEE). We concluded that the fixed effects model is inappropriate for two reasons. First, some of our important variables are time invariant [i.e., the Companies Act 2015 disclosure requirements (ComAct2015); the inclusion of IR into the reporting excellence awards (ExcelAward2016); and Sensitive Sector (Sector)], and second, a Hausman test also indicated that the random effects model fits the data better than fixed effects model. However, as Liang and Zeger (1986) show, while both the random effects and GEE models can be employed for our data, the GEE estimates are more robust and consistent and less subject to instability and convergence problems. Thus, in our main analyses, we employ the GEE models, whilst we use the random effects in our robustness tests.

\section{Results and discussion}

\subsection{Descriptive statistics}

The descriptive statistics of the disclosure scores are reported in Table 3. Panel A reports the disclosure scores at the aggregate level. In Panel B, we show disclosures on a yearly basis for trend analysis. In Panel $\mathrm{C}$, we provide independent t-tests comparing sustainability 
disclosures pre-and post-Companies Act requirements as well as comparing IR disclosures pre-and post-Reporting Excellence Awards. Our rationale for this is to understand whether there are any differences between the periods. We also compare in Panel C, the disclosures of IR adopters and non-adopters.

\section{[Insert Table 3 about here]}

Panel A shows that the mean (median) SR disclosure score is 68.9\% (68.4\%) compared to $30.4 \%$ (25.5\%) for the SR disclosure score. This suggests that the IR disclosures are substantially more than SR disclosures. In terms of trends, Panel B shows that both disclosure types have increased over time. However, we observe a greater increase in SR disclosures from $25.3 \%$ in 2010 to $36.3 \%$ in 2018 (a 4.2\% increase) compared to integrated report disclosures that increased from $58.8 \%$ to $77.6 \%$ in the same period (a $31.9 \%$ increase).

To provide additional insights into the disclosures, we test whether the disclosures differ in different periods. In particular, we test whether SR disclosures increased following the introduction of the Companies Act 2015 requirement to disclose nonfinancial information about environmental matters, the employees of the company and social and community issues. We also test whether IR disclosures improve following the decision to include them into the Reporting Excellence Awards. Finally, we test whether there are differences in SR and IR disclosures between companies that formally adopted integrated reporting and those that did not. The results are in Table 3, Panel C. The results indicate that the SR disclosures improved significantly following the introduction of mandatory disclosure in the Companies Act ( $p>0.012$ ). Similarly, IR disclosures also increased following the integration of integrated reporting in the Excellence Reporting Awards. The implication of these results is that regulatory pronouncements as well as the promotional efforts of the regulatory bodies and professional bodies are having the desired effects. Finally, Panel C indicates that for both SR and IR disclosures, companies that formally adopted integrated reporting have higher disclosures. This suggests that the adoption of integrated reporting leads to better information being made available to users of financial reports.

In Table 4, we provide descriptive statistics for the independent variables.

$$
\text { [Insert Table } 4 \text { about here] }
$$


The table indicates that board independence in listed companies is about $68.6 \%$ and the proportion of women on the board (gender diversity) is about 19.5\%, suggesting that gender diversity in Kenya is low. Audit committee independence is $52.9 \%$, suggesting that these committees include executive members. Block ownership is 33.7\% consistent with Waweru et al. (2019). The table also indicates that the mean company size is $\$ 748.42$ million $^{6}$, and the performance (return on assets) of the companies is 3.5\%. The leverage ratio is very high at $60.9 \%$ indicating that the companies rely on debt financing than they do on equity.

\subsection{Regression results}

As discussed in Cooke (1998), it is important to assess whether the dependent variable is normally distributed in disclosure regressions. We assessed our disclosure scores for normality violations. Whilst the violations, are not extreme, we follow Cooke (1998) and transform both dependent variables using normal scores. Cooke (1998) proposed the normal scores method as the most appropriate in transforming disclosure datasets. Following this process, we run correlations among the independent variables and inspect whether our variables are not highly correlated. These are reported in Table 5.

\section{[Insert Table 5 about here]}

As can be observed, the highest correlation coefficient is 0.531 between company size (total assets) and leverage, which is well below 0.8 , implying that multicollinearity is not a serious problem among the predictor variables (Marquardt, 1970; Vu et al., 2015). We perform multivariate analyses to establish the significant drivers of each reporting framework. The results of the generalized estimations equations in Table 6.

\section{[Insert Table 6 about here]}

For each disclosure score, we run three models. Models 1 to 3 relate to the SR Score, while Models 4 to 6 relate to the IR Score. For each score, we first run the analyses excluding the presence of foreign ownership and the interaction between foreign ownership and block ownership (Models 1 and 4). Next, we include foreign ownership (Models 2 and 5) and finally,

\footnotetext{
${ }^{6}$ Companies in Kenya Report in Ksh. Once we applied the statistics, we converted figures from Ksh. to \$ using an average rate of $\$ 1=$ Ksh.100.
} 
we introduce the interaction (Models 3 and 6). We include the models of the two scores in a single table to allow easier comparison of the results between the two. In comparing, we want to understand whether these are influenced by the same or similar factors. As Table 6 shows, the results are generally consistent between the two scores, although with some variations. We discuss the results in line with our hypotheses sections.

\subsubsection{Governance factors and, sustainability and integrated information}

In Section 3.1, we drew from both the agency and stakeholder theories and argued that there is information asymmetry between managers and stakeholders, including shareholders. We suggested that both shareholders and other stakeholders would be interested in understanding how companies create long-term value within the context of their environment. We also argued that corporate governance structures are important in minimising information asymmetries between the company and all its stakeholders. Consequently, we specified six hypotheses for each disclosure score relating to the relation between corporate governance structures and information disclosures.

In Hypotheses 1, we suggested that board independence and gender diversity are positively associated with SR disclosures (Hypotheses $1 \mathrm{a}$ and $1 \mathrm{~b}$ ) and IR disclosures (Hypotheses 1c and 1d). Table 6 shows that in both the SR and IR models, the coefficients of board independence (BIND) are not significant. Thus, both Hypotheses 1a and 1c are rejected, suggesting that board independence does not lead to better SR and IR disclosures. Our results are also inconsistent with Barako et al. (2006) and Waweru et al. (2019). They are contrary to the agency theory viewpoint that boards of directors, in particular outside directors, have responsibility for the disclosure policy (Healy and Palepu, 2001; Michelon and Parbonetti, 2012). This implies that outside directors may not be able to monitor managers effectively and promoting the interests of stakeholders as suggested by both the agency theory and stakeholder theory. One explanation for our results is that whereas Barako et al. (2006) and Waweru et al. (2019) examined voluntary (mainly financial) disclosures, our focus is on the new reporting framework, that is, sustainability and integrated reporting. In this context, outside board members may just be unfamiliar with these types of disclosures, and thus affecting their ability to monitor these disclosures.

Interestingly, we find that gender diversity (Gender) is positively and significantly related to both SR and IR disclosures at the 5\% level or better. Both Hypotheses $1 \mathrm{~b}$ and $1 \mathrm{~d}$ are, thus accepted. These results are consistent with other SR studies (e.g., Barako and Brown, 
2008; Post et al., 2011; Al-Shaer and Zaman, 2016) and IR studies (e.g., Frias-Aceituno et al., 2013; Gerwanski et al., 2019; Vitolla et al., 2019), suggesting that having more women on the board has value for sustainability and integrated reporting information. This is consistent with the agency theory literature (see Adams and Ferreira, 2009; Post et al., 2011) that argues that gender diversity enhances board independence and its ability to monitor managers. They are also supporting the stakeholder theory viewpoint that women board members would encourage better engagement with stakeholders (Abdullah and Valentine, 2009). Thus, to the extent that the provision of greater discloures is an attempt to improve dialogue with stakeholders (Gray et al., 1995; Adams, 2002), these results support the notion that women have more desire to build enhanced relationships with stakeholders than men (Gul et al., 2013; Al-Shaer and Zaman, 2016).

Our Hypotheses $2 \mathrm{a}$ and $2 \mathrm{~b}$ focus on the role of the audit committee. In particular, we posited that audit committee independence ( $A C I n d$ ) has positive effects on SR disclosures (Hypothesis 2a) and IR disclosures (Hypothesis 2b). We find that whereas, the coefficient of ACInd is positive and significant at $5 \%$ or better for SR disclosures, it is not significant for IR disclosures. Thus, we accept Hypothesis 2a and reject Hypothesis 2b, supporting the agency theory argument that the independence of audit committee members enhances monitoring of managers leading to better sustainability reporting. Our results for SR disclosures are consistent with several other studies (e.g., Arif et al., 2020) and other voluntary disclosure studies (e.g., Mangena and Pike, 2005; Karamanou and Vafeas, 2005; Li et al., 2012). Regarding IR disclosures, our results indicating no relationship with audit committee independence (Hypothesis 2b) are not consistent with Raimo et al. (2021) who reports positive effects of audit committee independence on IR adoption. However, we note that Raimo et al. (2021) examine adoption rather than the level of disclosures. It may be possible that the results are due to the independent audit committee members not being familiar with integrated reporting disclosures given that IR is a new concept of reporting. This may be compromising their ability to monitor managers and therefore, does not support agency theory.

Finally, we also hypothesised that block ownership would be positively related to SR disclosures (Hypothesis 4a) and IR disclosures (Hypothesis 4c). Following the findings of Barako et al. (2006) and Waweru et al. (2019), in the context of Kenya, we also posited that the effects of block ownership on SR disclosures (Hypothesis 4b) and IR disclosures (Hypothesis $4 \mathrm{~d}$ ) are moderated by the presence of foreign ownership. In relation to block ownership, we find that the relationship with SR disclosures is not significant, thus we reject 
Hypothesis 4a. These results are inconsistent with other similar studies reporting a positive and significant relationship with sustainability reporting (e.g., Mohd Ghazali, 2007; Darus et al., 2009; Saleh et al., 2010; Ntim and Soobaroyen, 2013). In contrast, we accept Hypothesis 4c about the positive relationship between block ownership and IR disclosures. The coefficient of block ownership is positive and significant at the $5 \%$ level or better, consistent with Raimo et al. (2020). These findings, which are partially in line with the agency theory, suggest that large shareholders demand enhanced integrated report information than sustainability information. A possible explanation is that IR disclosures are more informative as they help shareholders understand how long-term value is created within the context of the company's operating environment. Moreover, these disclosures could be seen as aiding the ability of large shareholders to monitor and ensure that managers do not act in their own interest at the expense of company value. Such understanding cannot be generated from enhanced sustainability information alone. In testing Hypotheses $4 \mathrm{~b}$ and $4 \mathrm{~d}$, we find that in both cases the coefficient of the interaction term (Block $x$ DForOwn) is not significant, thus both hypotheses are rejected. This suggests that the effects of block ownership are not moderated by the presence of foreign ownership. Hence, we conclude that it does not matter whether the large shareholders are foreign or local, they both find value (little value) in IR (SR) disclosures in monitoring managerial actions.

\subsubsection{Institutional related factors and, sustainability and integrated information}

We also argue that SR and IR disclosures in listed Kenyan companies could be driven by the requirements of the companies Act 2015 (Hypothesis 5a) and/or the promotional efforts of regulatory and professional bodies (Hypothesis 5b). In relation to Hypothesis 5a, Table 6 shows that the coefficient of ComAct2015 is positive but not significant, rejecting the hypothesis. This implies that the introduction of a requirement for listed companies to publish sustainability information in the Companies Act 2015 did not change company SR reporting practices. This is inconsistent with the institutional theory which suggests that coercive pressures, such as changes to legal requirements, would influence company disclosure practices (DiMaggio and Powell, 1983; Jackson and Apostolakou, 2010; Jensen and Berg, 2012). However, our results showing no significant relationship between SR and the introduction of the Companies Act 2015 may not necessarily mean that companies are not responding to the requirements. It is possible that by the time the requirement was 
incorporated into the Act in 2015, companies had already responded to the forthcoming regulation (see Gray and Roberts, 1989).

In relation to IR disclosure, we observe that the inclusion of integrated reporting into the reporting excellence awards had positive effects. The coefficient of ExcelAward2016 is highly significant and positive at the $1 \%$ level or better. Thus we accept Hypothesis $5 \mathrm{~b}$. Our results are consistent with the institutional theory. In this context, companies appear to respond to normative pressures to engage with integrated reporting. They also support Mathuva (2018) and Injeni et al. (2019) who suggested that companies do respond to reporting-excellence awards by improving their disclosures. This implies that the promotional efforts of CMA, ICPAK and NSE are gaining traction. The alternative explanation for our results, as documented by Gray and Roberts (1989), and also in line with the institutional theory, is that companies are already anticipating future regulation on integrated reporting (as happened with sustainability reporting), and thus taking the decision to engage with the process voluntarily.

We also hypothesised that certain industrial sectors, in particular, the manufacturing, construction and energy are likely to be motivated to increase both SR disclosures (Hypothesis 6a) and IR disclosures (Hypothesis 6b). The coefficient of the Sector is positive and significant at the $1 \%$ level or better for SR disclosures and at the $5 \%$ level or better for IR disclosures. Thus, we accept both Hypotheses 6a and 6b. Our results are consistent with other prior sustainability studies (e.g. Dennis et al., 2015; Botha and Middelberg, 2016; Garcia et al., 2017) and integrated reporting studies (e.g., Marrone and Oliva, 2019). Potentially, this practice is motivated by the desire to (i) reduce political costs or scrutiny (Adams, 2002; Gao et al., 2005) and/or (ii) be aligned with similar companies (Dye and Sridhar, 1985). This can be attributed to companies mimicking others in the same or similar industry as suggested by the institutional theory (Jackson and Apostolakou, 2010; Jensen and Berg, 2012).

\subsubsection{Control variables}

In relation to our control variables, Table 6 indicates, consistent with prior literature that company size is positively related to both SR and IR disclosures at the $1 \%$ level or better. However, profitability and leverage are not significant. Lastly, as expected, the dummy 
variable, IR Adoption, is highly significant and positive at $1 \%$ or better, suggesting that companies that have formally adopted integrated reporting provide SR and IR disclosures.

\subsection{Additional analyses}

In this section, we carry out additional analyses to test the robustness of our findings. First, in our main analyses, we run the regressions using the GEE model. In this section we re-run the regression using the random effects model. The results, as reported in Table 7 remain similar to those in Table 6.

\section{[Insert Table 7 about here]}

Second, we also run a battery of additional analyses for which we do not tabulate the results, but they are available upon request. The results in Tables 6 and 7 are based on disclosure scores that were transformed to normal scores. We re-run the regressions with the untransformed disclosure scores and our results are unchanged. Additionally, we include additional variables for board size, audit committee size, price-to book ratio, Big-4 auditors as well as replacing return on assets with return on equity. All the results hold. We also rerun by replacing our sector variables with the different industrial sectors (see Table 1) and our results show that manufacturing, construction and energy are still positively related to disclosure scores. These additional analyses suggest that our results are robust.

\section{Conclusion}

In this study, we set out to examine the level of disclosures over time relating to sustainability and integrated report information of companies listed on the NSE in order to understand how companies are embracing the newer reporting frameworks. This comprehensive investigation of corporate disclosures aids understanding of how companies are gradual transitioning to newer reporting frameworks. It also helps to understand whether the promotional efforts of regulatory authorities and professional bodies in Kenya are achieving intended outcomes. We also extend the analyses to examining the agency-related factors (i.e., corporate governance structures) and institutional-related factors (i.e., regulatory changes, and reporting excellence awards) that influence each type of disclosure. 
We find several interesting results. We find that the listed companies report substantially more IR related information than sustainability information. However, the growth in disclosures is greater in sustainability reporting increasing than integrated report information. This suggests that the efforts of the regulatory bodies and professional bodies in promoting these new reporting frameworks are having some effects. Moreover, we find significant variations in both disclosure types. We find that both agency-related factors and institutional-related factors influence the variations. In particular, we find that board gender diversity, audit committee independence and the presence of foreign ownership have positive effects on SR disclosures. In relation to the IR disclosures, our results also show that board gender diversity, audit committee independence and block ownership have positive effects on IR disclosures. We also find that whereas the Companies Act 2015 has little effects on sustainability reporting, the reporting excellence awards have significant effects. Thus, overall, the results demonstrate the similar factors influence both disclosures, and more importantly, the promotional efforts of regulatory bodies and professional bodies appear to have some effects.

Our paper contributes to those studies examining sustainability reports or integrated reports separately. We differ by examining the two types together and comparing whether they are influenced by the same or similar drivers. Our findings that the factors affecting these disclosure types are similar are interesting and inform future research. We extend sustainability reporting studies in Kenya by providing evidence on the effects of corporate governance structures and regulatory changes, reporting excellence awards and sector. As far as we are aware, no study has yet to examine institutional-related factors at the individual country-level, and therefore our study is an innovation. Moreover, as opposed to examining the adoption of integrated reporting, we examined the level of IR disclosures and the related drivers. We do not examine whether firms benefit from improvements in IR and SR disclosures. Thus, future research could consider the share valuation effects of enhanced IR and SR disclosures. Such understanding could encourage firms to enhance their disclosures. Finally, our study also offers important implications for policy and practice relating to sustainability and integrated reporting in Kenya. The results showing that companies respond to the promotional efforts of regulatory and professional bodies are significant. They demonstrate that their efforts are achieving outcomes and must be maintained or intensified. 
Our study is not without limitations. First, the study is country-specific, and therefore the results may not extend to other contexts. However, we believe our study is appropriate given the phenomenon under investigation and the fact that there are some unique features in Kenya, for instance, the Companies Act requirements and the reporting excellence awards. Future studies could consider other contexts or alternative a global sample. Second, this study has used an unweighted approach in scoring the disclosures, thus suggesting that all items are of equal importance. It is possible that firms report those items that are more important. While previous disclosure studies (e.g., Mangena and Pike, 2005) show no differences in results of weighted and unweighted scores, future research can still consider using a weighted index. Third, a more qualitative approach could be taken to explore the factors through interviews with the managers of sampled firms. Further, given the initiatives undertaken by the AIRC and stakeholders in various countries in Africa, additional studies are required to understand cross-country and other economic factors that influence transitioning to newer reporting frameworks. Finally, further research can be carried out on the incentives of companies adopting newer reporting. 


\section{References}

Abdullah, H., and Valentine, B. (2009), "Fundamentals and Ethics Theories of Corporate Governance", Middle Eastern Finance and Economics, Vol. 4 No. 4, pp.88-96.

Adams, C.A. (2002), "Internal organizational factors influencing corporate social and ethical reporting: beyond current theorizing", Accounting, Auditing \& and Accountability Journal, Vol. 15 No. 2, pp. 223-250.

Adams, R. and Ferreira, D. (2009), "Women in the boardroom and their impact on governance and performance," Journal of Financial Economics, Vol. 94 No.2, pp. 291-309.

Adhariani, D., and de Villiers, C. (2019), "Integrated reporting: perspectives of corporate report preparers and other stakeholders", Sustainability Accounting, Management and Policy Journal, Vol.10 No.1, pp. 126-156.

Ahearne, A.G., Griever, W.L. and Warnock, F.E., (2004), "Information costs and home bias: an analysis of US holdings of foreign equities," Journal of International Economics, Vol.62 No.3, pp. 313-336.

Ahmed Haji, A. and Anifowose, M. (2016), "The trend of integrated reporting practice in South Africa: ceremonial or substantive?", Sustainability Accounting, Management and Policy Journal, Vol. 7 No. 2, pp. 190-224.

Al-Shaer, H., and Zaman, M. (2018), "Credibility of sustainability reports: The contribution of audit committees", Business Strategy and the Environment, Vol.27 No.7, pp. 973-986.

Arif, M., Sajjad, A., Farooq, S., Abrar, M. and Joyo, A.S. (2020), "The impact of audit committee attributes on the quality and quantity of environmental, social and governance (ESG) disclosures", Corporate Governance, forthcoming, DOI: 10.1108/CG-06-2020-0243

Baiman, S. and Verrecchia, R. (1996), "The relation among capital markets, financial disclosure, production efficiency, and insider trading," Journal of Accounting Research, Vol. 34 No.1, pp. 1-22.

Bananuka, J., Tumwebaze, Z. and Orobia, L. (2019), "The adoption of integrated reporting: a developing country perspective", Journal of Financial Reporting and Accounting, Vol. 17 No. 1, pp. 2-23.

Barako, D. G., and Brown, A. M. (2008), “Corporate social reporting and board representation: evidence from the Kenyan banking sector", Journal of Management and Governance, Vol.12 No.4, pp. 309-324.

Barako, D. G., Hancock, P., and Izan, H. Y. (2006)," Factors influencing voluntary corporate disclosure by Kenyan companies", Corporate Governance: An International Review, Vol.14 No. 2, pp.107-125.

Barkemeyer, R., Preuss, L. and Lee, L. (2015), “On the effectiveness of private transnational governance regimes - evaluating corporate sustainability reporting according to the Global Reporting Initiative", Journal of World Business, Vol.50 No.2, pp. 312-325.

Barth M.E, Cahan, S.F., Chen, L. and Venter, E.R. (2017), "The economic consequences associated with integrated report quality: capital market and real effects", Accounting, Organizations \& Society, Vol. 62, pp. 43-64.

Bayoud, N., Kavanagh, M., and Slaughter, G. (2012), "Corporate Social Responsibility Disclosure and Employee Commitment: Evidence from Libya", International Journal of Economics and Finance, Vol. 4 No. 5, pp. 37-50.

Botha, M. J., and Middelberg, S. L. (2016), "Evaluating the adequacy of water-related reporting and disclosure by high-impact users in South Africa. Journal of Environmental Assessment Policy and Management", Vol.18 No.1, pp. 1-21. 
Bova, F. and Pereira, R. (2012), "The determinants and consequences of heterogeneous IFRS compliance levels following mandatory IFRS adoption: evidence from a developing country", Journal of International Accounting Research, Vol. 11 No. 1, pp. 83-111.

Bravo,F., Abad, M.C. and Trombetta, M. (2009), "Disclosure Indices Design: Does it Make a Difference?", Spanish Accounting Review, Vol. 12 No.2, pp.253-278.

Bravo, F. and Reguera-Alvarado, N. (2019), "Sustainable development disclosure: Environmental, social, and governance reporting and gender diversity in the audit committee", Business Strategy and the Environment, Vol.28 No.2, pp. 418-429.

Brown, J. and Fraser, M. (2006), "Approaches and perspectives in social and environmental accounting: an overview of the conceptual landscape", Business Strategy and the Environment, Vol. 15 No. 2, pp.103-117.

Churet, C., and Eccles, R. G. (2014), "Integrated reporting, quality of management, and financial performance”, Journal of Applied Corporate Finance, Vol. 26 No.1, pp. 56-64.

Conway, E. (2019), "Quantitative impacts of mandatory integrated reporting", Journal of Financial Reporting and Accounting, Vol. 17 No. 4, pp. 604-634.

Cooke, T. E. (1998), "Regression analysis in accounting disclosure studies", Accounting and Business Research, Vol.28 No.3, pp. 209-224.

Dagilienè, L. and Nedzinskienè, R. (2018), "An institutional theory perspective on nonfinancial reporting: The developing Baltic context", Journal of Financial Reporting and Accounting, Vol. 16 No. 4, pp. 490-521.

Darus, F., Arshad, R., Othman, S., and Jusoff, K. (2009), "Influence of institutional pressure and ownership structure on corporate social responsibility disclosure", Interdisciplinary Journal of Contemporary Research in Business, Vol.1 No.5, pp. 123-150

de Villiers, D. C., Rinaldi, L., and Unerman, J. (2014), "Integrated reporting: Insights, gaps and an agenda for future research", Accounting, Auditing \& Accountability Journal, Vol.27 No.7, pp.1042-1067.

Deegan, C. (2002), "Introduction: The legitimising effect of social and environmental disclosures - a theoretical foundation", Accounting, Auditing \& Accountability Journal, Vol. 15 No. 3, pp. 282-311.

Dennis, P., Connole, H., and Kraut, M. (2015), "The efficacy of voluntary disclosure: A study of water disclosure by mining companies using the global reporting initiative framework", Journal of Legal, Ethical and Regulatory Issues, Vol.18 No.2, pp.87-106.

Dienes, D., Sassen, R., and Fischer, J. (2016), "What are the drivers of sustainability reporting? A systematic review", Sustainability Accounting, Management and Policy Journal, Vol.7 No.2, pp.154-189.

Dilling, P. (2010), "Sustainability Reporting In A Global Context: What Are The Characteristics of Corporations That Provide High Quality Sustainability Reports An Empirical Analysis", International Business and Economics Research Journal, Vol.9 No.1, pp. 19-30.

DiMaggio, P.J. and Powell, W.W. (1983), “The Iron Cage Revisited: Institutional Isomorphism and Collective Rationality in Organizational Fields." American Sociological Review, Vol.48 No.2, pp. 147-160.

Dye, R.A. and Sridhar, S.S. (1985), "Industry-wide disclosure dynamics", Journal of Accounting Research, Vol. 33 No.1, pp. 157-174

Elliot, R. K.; and Jacobson P. D., (1994), "Costs and benefits of business information disclosure", Accounting Horizons, Vol. 8 No. 4, pp. 80-96.

Fama, E. F., and Jensen, M. C. (1983), "Separation of ownership and control”, The journal of law and Economics”, Vol.26 No.2, pp. 301-325. doi:10.1086/467037?

Freeman, R. E. (1984), "Strategic management: A stakeholder approach", New York: Cambridge University Press. 
Frias-Aceituno, J. V., Rodriguez-Ariza, L., and Garcia-Sanchez, I. M. (2013), "The role of the board in the dissemination of integrated corporate social reporting", Corporate Social Responsibility and Environmental Management, Vol. 20 No.4, pp. 219-233.

Frías-Aceituno, J. V., Rodríguez-Ariza, L., and García-Sánchez, I. M. (2014), "Is integrated reporting determined by a country's legal system? An exploratory study", Journal of Cleaner Production, Vol.44 No. 1, pp. 45-55.

Gao, S., Heravi, S., and Xiao, J. (2005), "Determinants of corporate social and environmental reporting in Hong Kong: a research note", Accounting Forum, Vol.29 No.2, 233-242.

Garcia, A.S., Mendes-Da-Silva, W. and Orsato, R.J. (2017), "Sensitive industries produce better ESG performance: Evidence from emerging markets", Journal of Cleaner Production, No.150, pp.135-147.

García-Sánchez I-M, Rodríguez-Ariza L, and Frías-Aceituno J-V (2013), "The cultural system and integrated reporting", International Business Review, Vol.22 No. 5, pp. 828-838.

Gerwanski, J., Kordsachia, O., and Velte, P. (2019), "Determinants of materiality disclosure quality in integrated reporting: Empirical evidence from an international setting", Business Strategy and the Environment, Vol. 28 No.5, pp. 750-770

Giner, B (1997), "The influence of company characteristics and accounting regulation on information disclosed by Spanish firms", European Accounting Review, Vol.6 No.1, pp. 45-68.

Girella, L., Rossi, P. and Zambon, S. (2019), "Exploring the firm and country determinants of the voluntary adoption of integrated reporting," Business Strategy and the Environment, Vol. 28 No.7, pp. 1323-1340.

Global Reporting Initiative (GRI) (2020), Sustainability reporting is growing, with GRI the global common language, GRI, Available at: https://www.globalreporting.org/aboutgri/news-center/2020-12-01-sustainability-reporting-is-growing-with-gri-theglobal-common-language/ (Accessed: $2^{\text {nd }}$ March 2021).

Government of Kenya (2015), The Companies Act, The Government Printer, Nairobi.

Gray, R., Kouhy, R. and Lavers, S. (1995), “Corporate social and environmental reporting: A review of the literature and a longitudinal study of UK disclosure", Accounting, Auditing and Accountability Journal, Vol. 8 No.2, pp. 47-77.

Gray, S.J. and Roberts, C.B. (1989), 'Voluntary information disclosure and the British multinationals: corporate perceptions of costs and benefits', in Hopwood, A.G. (eds). International pressures for accounting change. Hemel Hempstead: Prentice-Hall, pp. 11639.

GRI (Global Reporting Initiative (2013) "GRI Standards”, GRI. Amsterdam, The Netherlands. Available at: https://www2.globalreporting.org/standards/g4/Pages/default.aspx (Accessed: 24 June 2020).

GRI (Global Reporting Initiative) (2019), "First Global Sustainability Reporting Standards Set to Transform Business, GRI", GRI. Amsterdam, The Netherlands. Available at: https://www.globalreporting.org/information/about-gri/grihistory/Pages/GRI's\%20history.aspx (Accessed: 24 June 2020)

Guidara, A., Khlif, H., and Souissi, M. (2015), "Corporate social and environmental disclosure and corporate performance: Evidence from South Africa and Morocco", Journal of Accounting in Emerging Economies, Vol.5 No.1, pp.51-69.

Gul, F.A., Hutchinson, M. and Lai, K.M. (2013), "Gender-diverse boards and properties of analyst earnings forecasts", Accounting Horizons, Vol.27 No.3, pp. 511-538. 
Healy, P.M. and Palepu, K.G. (2001), "Information asymmetry, corporate disclosure, and the capital markets: A review of the empirical disclosure literature", Journal of Accounting and Economics, Vol.31 No.1-3, pp. 405-440.

IFAC (International Federation of Accountants) (2017), "The Accountant: African Integrated Reporting Committee announced at ACOA 2017", IFAC, Available at: https://integratedreporting.org/news/the-accountant-african-integrated-reportingcommittee-announced-at-acoa-2017/ (Accessed: 23 June 2020).

IIRC (International Integrated Reporting Council) (2013), "International <IR> Framework", IIRC, London, UK. Available at: https://integratedreporting.org/resource/international-ir-framework/ (Accessed: 24 June 2020).

Injeni G., McFie J., Mudida R. and Mangena M. (2019), “Current reporting and relationship with integrated reporting for listed companies in Kenya: disclosure levels and company factors", African Accounting Journal, Vol. 2 No.1, pp. 71-94.

International Accounting Standards Board (IASB) (2018), AP11A: Better Communication in Financial Reporting projects, IASB, Available at: https://cdn.ifrs.org//media/feature/meetings/2018/june/iasb/ap11a-di.pdf (Accessed: $2^{\text {nd }}$ March 2021).

International Integrated Reporting Council (IIRC) (2020), Celebrating Ten Years, IIRC, Available at: https://integratedreporting.org/10-years/10-years-summary (Accessed: $2^{\text {nd }}$ March 2021).

Isabel-María G., Martínez-Ferrero, J. and María-Antonia G., (2019), "Integrated reporting: The mediating role of the board of directors and investor protection on managerial discretion in munificent environments," Corporate Social Responsibility and Environmental Management, John Wiley \& Sons, Vol. 26 No.1, pp. 29-45.

Jackson, G., and Apostolakou, A. (2010), “Corporate Social Responsibility in Western Europe: An Institutional Mirror or Substitute?”, Journal of Business Ethics, Vol.94 No. 3, pp. 371394.

Jensen, J.C. and Berg, N. (2012), “Determinants of Traditional Sustainability Reporting Versus Integrated Reporting. An Institutionalist Approach", Business Strategy and the Environment, Vol. 21 No. 5, pp. 299-316.

Jensen, M. C., and Meckling, W. H. (1976), "Theory of the firm: Managerial behavior, agency costs and ownership structure", Journal of Financial Economics, Vol. 3 No. 4, pp. 305360.

Jensen, M.C. (1993), "The modern industrial revolution, exit and failure of internal control system", The Journal of Finance, Vol. XLVII No. 3, pp. 831-80.

Johnson, R. A., and Greening, D. W. (1999, "The Effects of Corporate Governance and Institutional Ownership Types on Corporate Social Performance", Academy of Management Journal, Vol. 42 No.5, pp. 564-576.

Kannenberg, I. and Schreck, P. (2019), "Integrated reporting: boon or bane? A review of empirical research on its determinants and implications," Journal of Business Economics, Springer, Vol. 89 No. 5, pp. 515-567.

Karamanou, I. and Vafeas, N. (2005), 'The association between corporate boards, audit committees, and management earnings forecasts: An empirical analysis', Journal of Accounting Research, Vol. 43 No.3, pp. 453-486.

Khasharmeh, H., and Suwaidan, M. (2010), "Social responsibility disclosure in corporate annual reports: evidence from the Gulf Cooperation Council countries", International Journal of Accounting, Auditing and Performance Evaluation, Vol. 6 No. 4, pp. 327-345. 
KIM (Kenya Institute of Management) (2019), “Company of The Year Awards”, KIM. Available at: https://www.kim.ac.ke/coya (Accessed: 23 June 2020).

KPMG International, GRI, UNEP and the Centre for Corporate Governance in Africa (2016), "Carrots Sticks Global trends in sustainability reporting regulation and policy", GRI. Available at: https://www.globalreporting.org/resourcelibrary/Carrots\%20and\%20Sticks2016.pdf (Accessed: 24 June 2020).

Krishnan, G.V. and Parsons, L.M. (2009), "Getting to the bottom line: an exploration of gender and earnings quality", Journal of Business Ethics, Vol. 78 No.1-2, pp.65-76.

Kuzey, C., \& Uyar, A. (2017), "Determinants of sustainability reporting and its impact on firm value: evidence from the emerging market of Turkey", Journal of Cleaner Production, Vol.143, pp.27-39.

Larrinaga-Gonzélez, C. and Perez-Chamorro, V. (2008), "Sustainability accounting and accountability in public water companies", Public Money and Management, Vol. 28 No. 6, pp. 337-343.

Le Roux, C and Pretorius, M. (2019), "Exploring the nexus between Integrated Reporting and Sustainability Embeddedness", Sustainability Accounting, Management and Policy Journal, Vol. 10 No. 5, pp. 822-843.

Li, J., Mangena, M. and Pike, R., (2012), "The effects of audit committee characteristics on intellectual capital disclosures", British Accounting Review, Vol. 44 No.2, pp. 98-110.

Liang, K. and Zeger, S. (1986), "Longitudinal data analysis using generalized linear models", Biometrika, Vol. 73 No. 1, pp. 13-22.

Liao, L., Luo, L. and Tang, Q. (2015), “Gender diversity, board independence, environmental committee and greenhouse gas disclosure", The British Accounting Review, Vol.47 No.4, pp. 409-424.

Lourenço, M. C., and Branco, M. (2015), "Main Consequences of IFRS Adoption: Analysis of Existing Literature and Suggestions for Further Research", Revista Contabilidade \& Finanças, Vol. 26 No. 68, pp. 126-139.

Manes-Rossi, F., Nicolò, G., Tudor, A. T., and Zanellato, G. (2020), "Drivers of integrated reporting by state-owned enterprises in Europe: a longitudinal analysis", Meditari Accountancy Research - forthcoming. https://doi.org/10.1108/MEDAR-07-2019-0532.

Mangena, M and Chamisa, E., (2008), "Corporate governance and incidences of listing suspension by the JSE Securities Exchange of South Africa: An empirical analysis", The International Journal of Accounting, Vol. 43 No.1, pp. 28-44.

Mangena, M. and V. Tauringana (2007), "Disclosure, corporate governance and foreign share ownership on the Zimbabwe Stock Exchange", Journal of International Financial Management and Accounting, Vol.18 No.2, pp. 53-85.

Mangena, M., and R. Pike (2005) 'The effect of audit committee shareholding, financial expertise and size on interim financial disclosures', Accounting and Business Research, 35 No. 4, 327-349.

Marquardt, D. W. (1970), “Generalized Inverses, Ridge Regression, Biased Linear Estimation, and Nonlinear Estimation", Technometrics, Vol. 12 No. 1, pp. 591-612.

Marrone, A., and Oliva, L. (2019), "Measuring the level of integrated reporting alignment with the $<\mathrm{IR}>$ framework", International Journal of Business and Management, Vol.14 No.12, pp.110-120.

Marston, C L. and Shrives, P.J. (1991), "The use of disclosure indices in accounting research: a review article”, British Accounting Review, Vol. 23 No. 3, pp.195-210.

Marston, C., and Polei, A. (2004), "Corporate reporting on the Internet by German companies", International Journal of Accounting Information Systems, Vol.5 No.3, pp. 285-311. 
Mathuva D.M., Mboya J.K., and McFie, J.B. (2017), “Achieving legitimacy through cooperative governance and social and environmental disclosure by credit unions in a developing country", Journal of Applied Accounting Research, Vol. 18 No. 2, pp. 162-184.

Mathuva, D.M. (2018), "An empirical analysis of the characteristics of savings and credit cooperatives participating in the reporting excellence awards in Kenya", Journal of Accounting in Emerging Economies, Vol. 8 No. 2, pp. 223-243.

Mathuva, D.M., Barako D.G., and Wachira, M.M. (2017), "The Economic Consequences of Environmental, Social and Governance Disclosures by Firms Quoted on the Nairobi Securities Exchange", African Accounting Finance Journal, Vol. 1 No.1, pp. 5-28.

Mathuva, D.M., Wachira, M.M. and Injeni, G.I. (2019), "Does Corporate Environmental Reporting Improve Stock Liquidity? Evidence from Kenyan Listed Firms", Environmental Reporting and Management in Africa (Advances in Environmental Accounting \& Management), Vol. 8 No. 1, pp. 9-34.

Mathuva, D.M. and Chong, H.G. (2018), "Impact of regulatory reforms on compliance with mandatory disclosures by savings and credit co-operatives in Kenya", Journal of Financial Regulation and Compliance, Vol. 26 No. 2, pp.246-270.

McFie, J. B. (2010), "High quality financial reporting, the case of Nairobi Stock Exchange", Lambert Academic Publishing.

Michelon, G. and Parbonetti, A. (2012), "The effect of corporate governance on sustainability disclosure", Journal of Management and Governance, Vol.16 No.3, pp. 477-509.

Modack, G. (2018), "Non-Financial Reporting: Baseline Survey", PAFA, South Africa.

Mohd Ghazali, N. A. (2007), "Ownership structure and corporate social responsibility disclosure: Some Malaysian evidence", Corporate Governance: The International Journal of Business in Society, Vol.7 No.3, pp. 251-266.

Mousa, G.A. (2010), "Stakeholder theory as an arch to manage successful legitimacy strategies," International Journal of Critical Accounting, Vol. 2 No.4, pp. 399-418.

Nalukenge, I., Nkundabanyanga, S.K. and Ntayi, J.M. (2018), "Corporate governance, ethics, internal controls and compliance with IFRS", Journal of Financial Reporting and Accounting, Vol. 16 No. 4, pp. 764-786.

Needles, B.E.Jr., Sarı, E.S., Güngör, N., Türel, A. and Can, M., (2019), "Sustainability reporting and integrated reporting: evidence from Turkish high-performance companies". Hitit University Journal of Social Sciences Institute, Vol. 12 No.2, pp. 257-270.

Nicholls, J.A. (2020), "Integrating financial, social and environmental accounting", Sustainability Accounting, Management and Policy Journal, Vol. 11 No. 4, pp. 745-769.

Nicolo, G., Zanellato, G., Manes-Rossi, F., and Tiron-Tudor, A. (2021), "Corporate reporting metamorphosis: empirical findings from state-owned enterprises", Public Money \& Management, Vol. 41 No.2, pp. 138-147.

Ntim, C. and Soobaroyen, T. (2013), "Black Economic Empowerment Disclosures by South African Listed Corporations: The Influence of Ownership and Board Characteristics", Journal of Business Ethics, Vol.116 No. 1, pp. 121-138.

Orazalin, N. and Mahmood, M. (2018), "Economic, environmental, and social performance indicators of sustainability reporting: Evidence from the Russian oil and gas industry," Energy Policy, Vol. 121 No. C, pp. 70-79.

Owusu-Ansah, S. (1998), "The Impact of Corporate Attributes on the Extent of Mandatory Disclosure and Reporting by Listed Companies in Zimbabwe", The International Journal of Accounting, Vol.33 No. 5, pp.605-629.

Pahuja, A., and Bhatia, B. S. (2012), "Determinants of corporate governance disclosures: Evidence from companies in Northern India”, IUP Journal of Corporate Governance, Vol. 9 No. 3, pp. 69-88. 
Petcharat, N. and Zaman, M. (2019), "Sustainability reporting and integrated reporting perspectives of Thai-listed companies", Journal of Financial Reporting and Accounting, Vol. 17 No. 4, pp. 671-694.

Plumlee, M. A., Brown, D., Hayes, R. M., and Marshall, R. S. (2015), “Voluntary environmental disclosure quality and firm value: Further evidence", Journal of Accounting and Public Policy, 34 No.4, 336-361.

Post, C., Rahman, N., and Rubow, E. (2011), “Green governance: Boards of directors' composition and environmental corporate social responsibility", Business and Society, Vol. 50 No.1, pp. 189-223.

Prado-Lorenzo, J. M. and Garcia-Sanchez, I. M. (2010), "The role of the board of directors in disseminating relevant information on greenhouse gases", Journal of Business Ethics, Vol.97 No. 3, pp. 391-424

Prado-Lorenzo, J.M., Gallego-Alvarez, I. and Garcia-Sanchez, I.M. (2009), "Stakeholder engagement and corporate social responsibility reporting: the ownership structure effect", Corporate Social Responsibility and Environmental Management, No.16, pp. 94107.

Raimo, N., Vitolla, F., Marrone, A. and Rubino, M. (2020), "The role of ownership structure in integrated reporting policies", Business Strategy and the Environment, Vol.29 No.6, pp.2238-2250.

Raimo, N., Vitolla, F., Marrone, A. and Rubino, M. (2021), "Do audit committee attributes influence integrated reporting quality? An agency theory viewpoint", Business Strategy and the Environment, Vol.30 No.1, pp. 522-534.

Rashid, A. (2018), "Does corporate social responsibility reporting enhance shareholders' value? A simultaneous equation approach", Journal of Financial Reporting and Accounting, Vol. 16 No. 1, pp. 158-178.

Republic of Kenya (2015), "The Companies Act No. 17 of 2015”, Government Printer, Nairobi. Reverte, C. (2009), "Determinants of corporate social responsibility disclosure ratings by Spanish listed firms", Journal of Business Ethics, Vol. 88 No. 2, pp. 351-366.

Rinaldi, L., Unerman, J. and de Villiers, C. (2018), "Evaluating the integrated reporting journey: insights, gaps and agendas for future research", Accounting, Auditing \& Accountability Journal, Vol. 31 No. 5, pp. 1294-1318.

Saleh, M., Zulkifli, N. and Muhamad, R. (2010), "Corporate social responsibility disclosure and its relation on institutional ownership: Evidence from public listed companies in Malaysia", Managerial Auditing Journal, Vol.25 No.6, pp. 591-613.

Sellami, M.Y., Dammak B., Hlima, N., and Jarboui, A. (2019), "An empirical investigation of determinants of sustainability report assurance in France", Journal of Financial Reporting and Accounting, Vol.17 No. 2, pp. 320-342.

Smith, J. V., Adhikari, A. and Tondkar, R.H. (1995), "Exploring differences in social disclosures internationally: A stakeholder perspective", Journal of Accounting and Public Policy, Vol. 24, pp.123-151.

Stubbs, W., and Higgins, C. (2014), "Integrated reporting and internal mechanisms of change", Accounting, Auditing \& Accountability Journal, Vol.27 No.7, pp.1068-1089.

Songini, L., Pistoni, A., Tettamanzi, P., Fratini, F., and Minutiello, V. (2021), "Integrated reporting quality and BoD characteristics: an empirical analysis", Journal of Management and Governance - forthcoming. https://doi.org/10.1007/s10997-02109568-8

Taber, K.S. (2018), “The Use of Cronbach's Alpha When Developing and Reporting Research Instruments in Science Education", Research in Science Education, Vol. 48 No. 6, pp.1273-1296. 
TI (Transparency International), (2019), “Corruption Perceptions Index 2019”, TI. Available at: https://tikenya.org/corruption-perceptions-index-2019/ (Accessed; 23 June 2020).

UNDP (2019), "2019 Human Development Index Ranking”, Available at; http://hdr.undp.org/en/content/2019-human-development-index-ranking (Accessed; 23 June 2020).

Vitolla, F., Raimo, N., and Rubino, M. (2019), "Board characteristics and integrated reporting quality: An agency theory perspective", Corporate Social Responsibility and Environmental Management, Vol. 27 No.2, pp.1152-1163

Vitolla, F., Raimo, N., Rubino, M. and Garzoni, A. (2020), "The determinants of integrated reporting quality in financial institutions", Corporate Governance, Vol.20 No.3, pp. 429444.

Wang, J., Song, L., and Yao, S. (2013), “The Determinants Of Corporate Social Responsibility Disclosure: Evidence From China”, Journal of Applied Business Research (JABR), Vol. 29 No.6, pp.1833-1848.

Waweru, N., Mangena, M. and Riro, K. (2019), "Corporate governance and corporate internet reporting in sub-Saharan Africa: the case of Kenya and Tanzania", Corporate Governance, Vol. 19 No. 4, pp. 751-773.

World Bank (2010), "Report On The Observance of Standards and Codes (ROSC) Kenya" Accounting and Auditing, the World Bank Group, Available at: http://documents.worldbank.org/curated/en/323221468048848759/pdf/625760W P0P118200Box0361486B0PUBLIC0.pdf (Accessed: 23 June 2020).

Yermack, D. (1996), "Higher market valuation of companies with a small board of directors", Journal of Financial Economics, Vol. 40 No. 2, pp.185-211.

Young, D. and Guenther, D.A., (2003), "Financial reporting environments and international capital mobility", Journal of Accounting Research, Vol.41 No. 4, pp. 553-579. 
Appendix 1: Construction of disclosure indices: Checklist of disclosure items

I: Sustainability information checklist

II: Integrated report information checklist

\begin{tabular}{|c|c|}
\hline 2000 to date: & December 2010 to date: \\
\hline $\begin{array}{l}\text { Economic } \\
\text { - Economic Performance } \\
\text { - Market Presence } \\
\text { - Indirect Economic Impacts } \\
\text { - Procurement Practices } \\
\text { Environmental } \\
\text { - Energy } \\
\text { - Water } \\
\text { - Biodiversity } \\
\text { - Emissions } \\
\text { - Effluents \& Waste } \\
\text { - Products \& Services } \\
\text { - Compliance } \\
\text { - Transport } \\
\text { - Overall environmental expenditure } \\
\text { - Supplier Assessment } \\
\text { - Grievance Mechanism }\end{array}$ & $\begin{array}{l}\text { Content elements only: } \\
\text { Organizational overview } \\
\text { - Organization's mission and vision } \\
\text { - Culture, ethics and values } \\
\text { - Ownership and operating structure } \\
\text { - Principal activities and markets } \\
\text { - Competitive landscape and market } \\
\text { - positioning } \\
\text { - } \text { Kesition within the value chain } \\
\text { External environment } \\
\text { - Legal } \\
\text { - Commercial } \\
\text { - Social } \\
\text { - Environmental } \\
\text { - Political }\end{array}$ \\
\hline
\end{tabular}

Social

- Employment

- Labour/management relations

- Occupational health and safety

- Training and education

- Diversity and equal opportunity

- Equal renumeration for women and men

- Supplier assessment for labour practices

\section{Governance}

- Organization's leadership structure including skills and diversity

- Specific Processes used to make strategic decisions

- Actions to monitor strategic direction

- Organization's culture, ethics and values

- Governance practices that exceed legal requirements

- The responsibility those charged with governance

- Labour practices grievance mechanisms

- How remuneration and incentives are linked to value creation

- Non discrimination Business model

- Freedom of association and collective bargaining

- Child labour

- Forced or compulsory labour

- Security practices

- Indigenous rights

- Assessment

- Supplier human rights assessment

- Human rights grievance assessment

- Local communities

- Key Inputs

- Business activities

- Outputs

- Outcomes (Positive and negative) (i)Internal (employee morale, reputation, revenues, cashflows)

(ii) External (tax payments, customer satisfaction, brand loyalty)

- A diagram highlighting key elements of Business model

- Logical narrative flow of the business 


\section{I: Sustainability information checklist \\ - Anti-corruption \\ - Public policy \\ - Anti-competitive behaviour \\ - Compliance \\ - Supplier assessment for impacts on society \\ - Grievance mechanisms for impacts on society \\ - Customer health and safety \\ - Product and service labelling \\ - Marketing communications \\ - Customer privacy \\ - Compliance}

IV: CG: Governance (CMA/OECD)

- The financial and operating results of the company.

- Company objectives and non-financial information.

- Major share ownership, including beneficial owners, and voting rights.

- Remuneration of members of the board and key executives

- Information about board members, including their qualifications, the selection process, other company directorships and whether they are regarded as independent by the board.

- Related party transactions.

- Foreseeable risk factors.

- Issues regarding employees and other stakeholders.

- Governance structures and policies, including the content of any corporate governance code or policy and the process by which it is implemented.
II: Integrated report information checklist

- Critical stakeholders and other dependencies

Risks and opportunities

- Specific source of risks and opportunities

- Organization's assessment of the likelihood and impact of risk

- Steps being taken to manage key risks

- Materiality

Strategy and resource allocation

- Organization's short-, medium- and longterm strategic objectives

- Strategies in place to achieve those strategic objectives

- Resource allocation plans to implement the strategy

- Method of measuring achievements and target outcomes

- Differentiation and advantage and enable it create value

- Stakeholder engagements

Performance

- Quantitative indicators with respect to targets, risks and opportunities

- Organization's effects on the capitals

- The state of key stakeholder relationships and responses to their needs

- Linkages between past, current performance and future outlook

- Key performance indicators

Outlook

- Expectations about the external environment in the short, medium and long term

- How those expectations will affect the organization 


\begin{tabular}{lc}
\hline I: Sustainability information checklist & II: Integrated report information checklist \\
\hline & Organization readiness to respond to \\
critical challenges that are likely to arise \\
- Management of key relationships \\
- Projections and a summary of related \\
assumptions
\end{tabular}

Source: IIRC (2010), and GRI (Global Reporting Initiative, 2013). 
Table 1: Sample Selection

\begin{tabular}{|c|c|c|c|}
\hline Panel A: Sample selection & Firms & Firm-years & $\%$ \\
\hline Listed firms as of 31 December 2019 & 66 & 594 & $100 \%$ \\
\hline Less: Firms suspended from trading & $(4)$ & $(36)$ & $(6 \%)$ \\
\hline Less: Firms with less than 3-year continuous data & (9) & $(81)$ & $(14 \%)$ \\
\hline Less: Missing observations & & $(58)$ & $(10 \%)$ \\
\hline Final sample representation & 53 & 419 & $71 \%$ \\
\hline \multicolumn{4}{|l|}{ 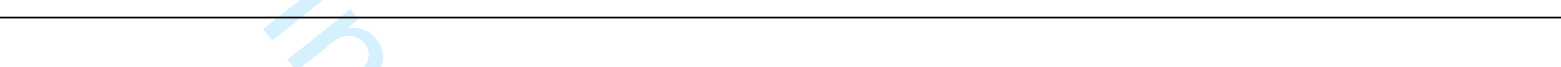 } \\
\hline Panel B: Sectoral representation & Firms & Firm-years & $\%$ \\
\hline Agricultural & 3 & 23 & $5 \%$ \\
\hline Automobile & 2 & 18 & $4 \%$ \\
\hline Banking & 10 & 87 & $21 \%$ \\
\hline Commercial and Services & 9 & 65 & $16 \%$ \\
\hline Construction & 5 & 44 & $11 \%$ \\
\hline Energy & 5 & 42 & $10 \%$ \\
\hline Insurance & 6 & 43 & $10 \%$ \\
\hline Investments & 4 & 25 & $6 \%$ \\
\hline Manufacturing & 8 & 63 & $15 \%$ \\
\hline Telecommunications & 1 & 9 & $2 \%$ \\
\hline Total & 53 & 419 & $100 \%$ \\
\hline
\end{tabular}


Table 2: Variable Definitions

\begin{tabular}{|c|c|c|c|c|}
\hline Abbreviation & Variable & Measurement & Data source & $\begin{array}{l}\text { Model in } \\
\text { which the } \\
\text { variable is } \\
\text { used }\end{array}$ \\
\hline 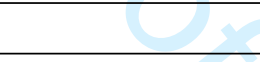 & \multicolumn{2}{|c|}{ Response variables } & & \\
\hline SR_Score & $\begin{array}{l}\text { The } \\
\text { sustainability } \\
\text { reporting } \\
\text { disclosure } \\
\text { score }\end{array}$ & $\begin{array}{l}\text { Sustainability score } \\
\text { of a company } \\
\text { measured as an } \\
\text { index developed } \\
\text { using a checklist } \\
\text { developed from } \\
\text { GRI (2013) }\end{array}$ & $\begin{array}{l}\text { Sustainability } \\
\text { reports and } \\
\text { Annual report }\end{array}$ & SR Model \\
\hline IR_Score & $\begin{array}{l}\text { The integrated } \\
\text { reporting } \\
\text { disclosure } \\
\text { score }\end{array}$ & $\begin{array}{l}\text { Integrated report } \\
\text { information } \\
\text { disclosure score of } \\
\text { a company } \\
\text { measured as an } \\
\text { index developed } \\
\text { using a checklist } \\
\text { developed from } \\
\text { IIRC (2010) }\end{array}$ & $\begin{array}{l}\text { Annual report } \\
\text { and/or } \\
\text { Integrated } \\
\text { reports }\end{array}$ & IR Model \\
\hline & Predic & or variables & & \\
\hline (a) Corpor & governance vari & bles & & \\
\hline$\overline{\text { Bind }}$ & $\begin{array}{l}\text { Board } \\
\text { independence }\end{array}$ & $\begin{array}{l}\text { = No of } \\
\text { Independent } \\
\text { directors to Total } \\
\text { Number of } \\
\text { Directors }\end{array}$ & orts & $\begin{array}{l}\text { SR and IR } \\
\text { Models }\end{array}$ \\
\hline Gender & $\begin{array}{l}\text { Gender } \\
\text { diversity in } \\
\text { the board }\end{array}$ & $\begin{array}{l}=\text { the number of } \\
\text { women in the } \\
\text { board to total } \\
\text { board members }\end{array}$ & $\begin{array}{l}\text { Annual reports, } \\
\text { CG reports }\end{array}$ & $\begin{array}{l}\text { SR and IR } \\
\text { Models }\end{array}$ \\
\hline ACInd & $\begin{array}{l}\text { Independence } \\
\text { of the audit } \\
\text { committee }\end{array}$ & $\begin{array}{l}=\text { number of } \\
\text { independent } \\
\text { members in the } \\
\text { audit committee to } \\
\text { total audit } \\
\text { committee size }\end{array}$ & $\begin{array}{l}\text { Annual reports, } \\
\text { CG reports }\end{array}$ & $\begin{array}{l}\text { SR and IR } \\
\text { Models }\end{array}$ \\
\hline
\end{tabular}




\begin{tabular}{|c|c|c|c|c|}
\hline Abbreviation & Variable & Measurement & Data source & $\begin{array}{l}\text { Model in } \\
\text { which the } \\
\text { variable is } \\
\text { used }\end{array}$ \\
\hline Block & $\begin{array}{l}\text { Block share } \\
\text { ownership }\end{array}$ & $\begin{array}{l}=\text { Total ownership } \\
\text { by shareholders } \\
\text { owing } 5 \% \text { or more } \\
\text { of the outstanding } \\
\text { shares }\end{array}$ & $\begin{array}{l}\text { Annual reports, } \\
\text { CG reports }\end{array}$ & $\begin{array}{l}\text { SR and IR } \\
\text { Models }\end{array}$ \\
\hline DForOwn & $\begin{array}{l}\text { Dummy } \\
\text { Foreign } \\
\text { Ownership }\end{array}$ & $\begin{array}{l}=\text { Dummy Variable } \\
\text { taking the value of } \\
1 \text { if there is a } \\
\text { presence of foreign } \\
\text { shareholders and } 0 \\
\text { otherwise }\end{array}$ & $\begin{array}{l}\text { Annual reports, } \\
\text { CG reports }\end{array}$ & $\begin{array}{l}\text { SR and IR } \\
\text { Models }\end{array}$ \\
\hline ComAct 2015 & $\begin{array}{l}\text { Year when } \\
\text { Company Act } \\
2015 \text { was } \\
\text { operational }\end{array}$ & $\begin{array}{l}=\text { Dummy Variable } \\
\text { taking the value of } \\
1 \text { for } 2016 \text { and } \\
\text { onwards, and } 0 \text { for } \\
\text { pre- } 2016\end{array}$ & $\begin{array}{l}\text { Government of } \\
\text { Kenya (2015) }\end{array}$ & SR Model \\
\hline ExcelAward2016 & $\begin{array}{l}\text { Reporting } \\
\text { Excellence } \\
\text { Awards }\end{array}$ & $\begin{array}{l}\text { Dummy variable } \\
\text { taking the value of } \\
1 \text { in } 2016 \text { and } \\
\text { subsequent years; } \\
0 \text { if pre } 2016\end{array}$ & ICPAK & IR model \\
\hline Sector & $\begin{array}{l}\text { Sector, being } \\
\text { manufacturing } \\
\text { construction } \\
\text { and energy }\end{array}$ & $\begin{array}{l}\text { = Dummy variable } \\
\text { taking the value of } \\
1 \text { if in } \\
\text { manufacturing, } \\
\text { construction or } \\
\text { energy sectors and } \\
0 \text { for other sectors }\end{array}$ & $\begin{array}{l}\text { Nairobi } \\
\text { Securities } \\
\text { Exchange } \\
\text { Website }\end{array}$ & $\begin{array}{l}\text { SR and IR } \\
\text { Models }\end{array}$ \\
\hline
\end{tabular}
(b) Control variables

42
43
44
45
46
47
48
49
50
51
52
53
54
55
56
57
58
59
60

$R O A$

$R O A$

Lev

Size as
measured by
Assets

$\begin{array}{ll}\text { Assets } & \text { Total Assets } \\ \text { Alternative } & =\text { Net Income to }\end{array}$

Measure of Total Assets

Profitability

Leverage = Total Liabilities to Total Assets 
Table 3, Panel A: Descriptive Statistics for Dependent Variables

\begin{tabular}{lcccccc}
\hline Disclosure Score & $N$ & Mean & StDev & Min. & $\begin{array}{c}\text { Media } \\
n\end{array}$ & Max. \\
\hline SR_Score & 419 & $30.40 \%$ & $17.80 \%$ & $3.90 \%$ & $25.5 \%$ & $98.00 \%$ \\
IR_Score & 419 & $68.90 \%$ & $18.00 \%$ & $26.10 \%$ & $68.4 \%$ & $100.00 \%$ \\
\hline
\end{tabular}

Table 3, Panel B: Trend analysis of Sustainability and Integrated Reporting Disclosures

\begin{tabular}{lrrrrrrrrr}
\hline & 2010 & 2011 & 2012 & 2013 & 2014 & 2015 & 2016 & 2017 & 2018 \\
\hline Sustainabilit & 25.32 & 26.14 & 27.48 & 31.10 & 30.96 & 30.60 & 30.44 & 33.21 & 36.26 \\
y Reporting & $\%$ & $\%$ & $\%$ & $\%$ & $\%$ & $\%$ & $\%$ & $\%$ & $\%$ \\
Integrated & 58.96 & 63.36 & 64.22 & 66.58 & 69.57 & 71.34 & 70.87 & 74.38 & 77.59 \\
Reporting & $\%$ & $\%$ & $\%$ & $\%$ & $\%$ & $\%$ & $\%$ & $\%$ & $\%$ \\
\hline
\end{tabular}

Table 3, Panel C: Comparison of Disclosures and t-tests and F tests for Sustainability and IR

\begin{tabular}{lccccc}
\hline Disclosure category & $N$ & Mean & Std. Dev. & tand F & $p$-value \\
\hline SR Before CA 2015 & 146 & $30.88 \%$ & $17.64 \%$ & & \\
SR After CA 2015 & 146 & $33.52 \%$ & $19.92 \%$ & & \\
Difference & 146 & $30.38 \%$ & $17.73 \%$ & $\mathrm{t}=-1.576$ & 0.11723 \\
\hline & & & & & \\
IR Before Excellence Award & 147 & $69.20 \%$ & $17.53 \%$ & & \\
IR After Excellence Award & 147 & $74.09 \%$ & $17.34 \%$ & & \\
Difference & 147 & $68.93 \%$ & $17.99 \%$ & $\mathrm{t}=-2.855$ & 0.00498 \\
\hline & & & & & \\
SR -IR Adopters & 364 & $43.71 \%$ & $20.00 \%$ & & \\
SR - NonIR Adopters & 55 & $28.37 \%$ & $16.44 \%$ & & \\
Difference & 419 & $30.49 \%$ & $17.8 \%$ & $* \mathrm{~F}=38.94$ & 0.000 \\
& & & & & \\
IR -IR Adopters & 364 & $89.62 \%$ & $8.28 \%$ & & \\
IR - NonIR Adopters & 55 & $65.80 \%$ & $17.01 \%$ & & \\
Difference & 419 & $30.49 \%$ & $18.0 \%$ & $* * \mathrm{~F}=103.6$ & 0.000 \\
\hline *F_critical = 6.36 and & $* * \mathrm{~F}$-critical & &
\end{tabular}


Journal of Financial Reporting and Accounting

Page 42 of 48

1
2
3
4
5
6
7
8
9
10
11
12
13
14
15
16
17
18
19
20
21
22
23
24
25
26
27
28
29
30
31
32
33
34
35
36
37
38
39
40
41
42
43
44
45
46
47
48
49
50
51
52
53
54
55
56
57
58
59
60

Table 4: Descriptive statistics for Independent Variables

\begin{tabular}{lrrrrrr}
\hline Variable & Obs & Mean & Median & Std. Div. & Min & Max \\
\hline Prp_Ind Board & 419 & $68.64 \%$ & $67.00 \%$ & $12.05 \%$ & $33.00 \%$ & $92.00 \%$ \\
Prp_WOB & 419 & $19.52 \%$ & $20.00 \%$ & $13.35 \%$ & $0.00 \%$ & $67.00 \%$ \\
Prop_ACInd & 419 & $52.92 \%$ & $40.00 \%$ & $31.03 \%$ & $0.00 \%$ & $100.00 \%$ \\
Block Ownership & 419 & $33.70 \%$ & $30.00 \%$ & $17.29 \%$ & $6.00 \%$ & $74.00 \%$ \\
Foreign Owned & 419 & 0.3866 & 0 & 0.4875 & 0 & 1 \\
Assets(\$m) & 419 & 748.42 & 240.99 & $1,139.66$ & 3.21 & $7,143.13$ \\
RDA & 419 & $3.50 \%$ & $4.00 \%$ & $13.79 \%$ & $-170.00 \%$ & $38.00 \%$ \\
Lev & 419 & $60.96 \%$ & $62.00 \%$ & $28.61 \%$ & $2.00 \%$ & $331.00 \%$ \\
\hline
\end{tabular}


Page 43 of 48

Journal of Financial Reporting and Accounting

$$
\begin{aligned}
& 1 \\
& 2 \\
& 3 \\
& 4 \\
& 5 \\
& 6 \\
& 7 \\
& 8 \\
& 9 \\
& 10 \\
& 11 \\
& 12 \\
& 13 \\
& 14 \\
& 15 \\
& 16 \\
& 17 \\
& 18 \\
& 19 \\
& 20 \\
& 21 \\
& 22 \\
& 23 \\
& 24 \\
& 25 \\
& 26 \\
& 27 \\
& 28 \\
& 29 \\
& 30 \\
& 31 \\
& 32 \\
& 33 \\
& 34 \\
& 35 \\
& 36 \\
& 37 \\
& 38 \\
& 39 \\
& 40 \\
& 41 \\
& 42 \\
& 43 \\
& 44 \\
& 45 \\
& 46 \\
& 47 \\
& 48 \\
& 49 \\
& 50 \\
& 51 \\
& 52 \\
& 53 \\
& 54 \\
& 55 \\
& 56 \\
& 57 \\
& 58 \\
& 59 \\
& 60
\end{aligned}
$$

\begin{tabular}{lrrrrrrr}
\hline & Prp_Ind & Prp_WOB & PropACInd & Blocks & LnAsset & KOA & Lev \\
\hline Prp_Ind Bd & 1 & & & & & & \\
Prp_WOB & -0.1159 & 1 & & & & & \\
Prop. ACInd & $0.2185^{* * *}$ & 0.0684 & 1 & & & & \\
Block Share & -0.0716 & $-0.143^{* * *}$ & $-0.183^{* * *}$ & 1 & & \\
LN Assets & $0.1654^{* * *}$ & $0.150^{* * *}$ & $0.344^{* * *}$ & -0.1113 & 1 & & \\
KOA & $-0.190^{* * *}$ & -0.0093 & 0.0571 & 0.018 & -0.1029 & 1 & \\
Lev & $0.1715^{* * *}$ & 0.0746 & $0.148^{* * *}$ & $-0.129^{* * *}$ & $0.5310^{* * *}$ & $-0.44^{* * *}$ & 1 \\
\hline
\end{tabular}

***Significant at the $1 \%$ level. 
Table 6: The Random Effects Model for Multivariate Analysis (GEE Model)

\begin{tabular}{|c|c|c|c|c|c|c|}
\hline Dependent variable & & tainability Report & ing & & tegrated Reportin & \\
\hline Model No. & 1 & 2 & 3 & 4 & 5 & 6 \\
\hline Number of observations & 419 & 419 & 419 & 419 & 419 & 419 \\
\hline Number of groups & 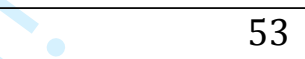 & 53 & 53 & 53 & 53 & 53 \\
\hline Prob $>$ chi $^{2}$ & 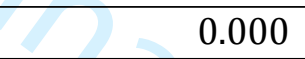 & 0.000 & 0.000 & 0.000 & 0.000 & 0.000 \\
\hline Variables & Coeff. (z-Score) & Coeff. (z-Score) & Coeff. (z-Score) & Coeff. (z-Score) & Coeff. (z-Score) & Coeff. (z-Score) \\
\hline Proportion_WOB & $0.778(2.22)^{* *}$ & $0.764(2.15)^{* *}$ & $0.749(2.01)^{* *}$ & $0.917(2.47)^{* *}$ & $0.916(2.47)^{* *}$ & $0.907(2.42)^{* *}$ \\
\hline $\begin{array}{l}\text { Proportion_AC } \\
\text { Independence }\end{array}$ & $0.281(1.67)^{*}$ & $0.297(1.75)^{*}$ & $0.302(2.25)^{*}$ & $-0.074(-0.35)$ & $-0.070(-0.33)$ & $-0.066(-0.31)$ \\
\hline Block Ownership & $0.672(1.27)$ & $0.699(1.39)$ & $0.907(1.37)$ & $0.984(2.48)^{* *}$ & $0.997(2.51)^{* *}$ & $1.126(2.22)^{* *}$ \\
\hline Excel Award 2016 & & +3 & 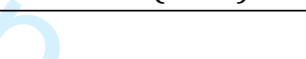 & $0.244(4.45)^{* * *}$ & $0.247(4.40)^{* * *}$ & $0.240(4.28)^{* * *}$ \\
\hline Foreign Ownership & & $0.437(2.54) * *$ & $0.434(2.49)^{* *}$ & & $0.152(0.86) * *$ & $0.151(0.86)$ \\
\hline Size - Log of Assets & $0.197(3.08)^{* * *}$ & $0.213(3.47)^{* * *}$ & $0.215(3.26)^{* * *}$ & $0.269(3.73)^{* * *}$ & $0.273(3.71)^{* * *}$ & $0.275(3.67)^{* * *}$ \\
\hline Return on Assets & $0.544(0.99)$ & $0.528(0.97)$ & $0.510(1.02)$ & $-0.082(-0.24)$ & $-0.081(-0.24)$ & $-0.095(0.27)$ \\
\hline Leverage & $0.137(0.50)$ & $0.121(0.53)$ & $0.114(0.59)$ & $-0.007(-0.05)$ & $-0.001(-0.00)$ & $0.007(-0.04)$ \\
\hline IR adopter & $0.325(1.88) *$ & $0.325(1.87) *$ & $0.334(1.90) *$ & $0.564(4.88)^{* * *}$ & $0.564(4.86)^{* * *}$ & $0.569(5.00) * * *$ \\
\hline Constant & $-2.146(-4.12)^{* * *}$ & $-2.425(-4.68)^{* * *}$ & $-2.513(-4.55) * * *$ & $-2.231(-4.47)^{* * *}$ & $-2.318(-4.37)^{* * *}$ & $-2.376(-4.16) * * *$ \\
\hline
\end{tabular}

$* 10 \%$ significance level; ${ }^{* *} 5 \%$ Significance level and ${ }^{* * *} 1 \%$ Significance level. 
Table 7: The Random Effects (GLS Model)

\begin{tabular}{|c|c|c|c|c|c|c|}
\hline Dependent variable & \multicolumn{3}{|c|}{ Sustainability Reporting } & \multicolumn{3}{|c|}{ Integrated Reporting } \\
\hline Model No. & 1 & 2 & 3 & 4 & 5 & 6 \\
\hline Number of Observations & 419 & 419 & 419 & 419 & 419 & 419 \\
\hline Number of Groups & 8 & 53 & 53 & 53 & 53 & 53 \\
\hline Wald chi2(11) & 78.69 & 89.42 & 92.62 & 217.35 & 218.47 & 226.83 \\
\hline Prob > chi2 & 0.000 & 0.000 & 0.000 & 0.000 & 0.000 & 0.000 \\
\hline & $P$ & 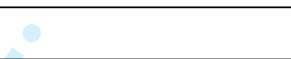 & & & & \\
\hline Variables & $\begin{array}{r}\text { Coeff. (z- } \\
\text { Score) } \\
\end{array}$ & Coeff. (z-Score) & $\begin{array}{r}\text { Coeff. (z- } \\
\text { Score) } \\
\end{array}$ & $\begin{array}{r}\text { Coeff. (z- } \\
\text { Score) } \\
\end{array}$ & $\begin{array}{r}\text { Coeff. (z- } \\
\text { Score) } \\
\end{array}$ & $\begin{array}{r}\text { Coeff. (z- } \\
\text { Score) } \\
\end{array}$ \\
\hline Proportion_Ind. Board & $0.133(0.41)$ & $0.123(0.38)$ & $0.137(0.43)$ & $0.052(0.17)$ & $0.045(0.15)$ & $0.058(0.19)$ \\
\hline Proportion_WOB & $0.778(2.19)^{* *}$ & $0.770(2.13)^{* *}$ & $0.755(2.13)^{* *}$ & $0.921(2.47)^{* *}$ & $0.918(2.45)^{* *}$ & $0.910(2.41)^{* *}$ \\
\hline $\begin{array}{l}\text { Proportion_AC } \\
\text { Independence }\end{array}$ & $0.282(1.65) *$ & $0.293(1.68) *$ & $0.298(1.68)^{*}$ & $-0.067(-0.31)$ & $-0.064(-0.30)$ & $-0.057(-0.39)$ \\
\hline Block Ownership & $0.672(1.26)$ & $0.705(1.38)$ & $0.937(1.32)$ & $0.962(2.40) * *$ & $0.978(2.44)^{* *}$ & $1.116(2.19)^{* *}$ \\
\hline Excel Award 2016 & & & 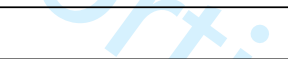 & $0.243(4.39)^{* * *}$ & $0.242(4.34)^{* * *}$ & $0.239(4.21)^{* * *}$ \\
\hline Foreign Ownership & & $0.434(2.8) * *$ & $0.431(2.41)^{* *}$ & & $0.153(0.85)^{* *}$ & $0.151(0.85)$ \\
\hline Block $x$ Foreign & & & $-0.505(-0.51)$ & 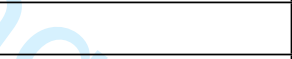 & & $-0.324(-0.39)$ \\
\hline Companies Act 2015 & $0.146(1.69) *$ & $0.139(1.59)$ & $0.136(1.51)$ & 3 & & \\
\hline Sector Code & $0.772(3.72)^{* * *}$ & $0.763(3.89)^{* * *}$ & $0.778(3.89)^{* * *}$ & $0.381(2.11)^{* *}$ & $0.378(2.11)^{* *}$ & $0.388(2.12)^{* *}$ \\
\hline Size - Log of Assets & $0.197(3.05)^{* * *}$ & $0.210(3.29)^{* * *}$ & $0.211(3.25)^{* * *}$ & $0.270(3.78)^{* * *}$ & $0.274(3.75)^{* * *}$ & $0.276(3.74)^{* * *}$ \\
\hline Return on Assets & $0.544(0.98)$ & $0.538(0.98)$ & $0.519(0.95)$ & $-0.092(-0.26)$ & $-0.090(-0.26)$ & $-0.109(-0.31)$ \\
\hline Leverage & $0.116(0.49)$ & $0.131(0.56)$ & $0.126(0.54)$ & $-0.015(-0.09)$ & $-0.007(-0.04)$ & $-0.0157(-0.10)$ \\
\hline IR adopter & $0.325(1.86) *$ & $0.324(1.83) *$ & $0.334(1.85) *$ & $0.564(4.84)^{* * *}$ & $0.564(4.81)^{* * *}$ & $0.571(4.96)^{* * *}$ \\
\hline Constant & $\begin{array}{r}-2.147(-4.07) \\
* * *\end{array}$ & $\begin{array}{r}-2.407(-4.51) \\
* * *\end{array}$ & $\begin{array}{r}-2.503(-4.42) \\
* * *\end{array}$ & $\begin{array}{r}-2.233(-4.49) \\
* * *\end{array}$ & $\begin{array}{r}-2.321(-4.37) \\
* * *\end{array}$ & $\begin{array}{r}-2.386(-4.21) \\
* * *\end{array}$ \\
\hline
\end{tabular}

*10\% significance level; **5\% Significance level and *** 1\% Significance level. 


\section{Response to reviewers' comments}

RE: JFRA-10-2020-0305_R2: "Agency and institutional related factors and the heterogeneity of sustainability and integrated report information disclosures in Kenya"

\section{Dear Editor}

Below is a matrix containing our detailed response to reviewer comments. We have diligently responded to each, and every comment raised by the reviewer as per your email dated 23rd May 2021. The corrections made on the revised manuscript are highlighted in yellow.

\begin{tabular}{|c|c|}
\hline Reviewers Comments & Authors Comments \\
\hline $\begin{array}{l}\text { Additional Questions: } \\
\text { 1. Originality: Does the paper contain new and } \\
\text { significant information adequate to justify } \\
\text { publication? } \\
\text { The paper contains a moderate degree of } \\
\text { originality. }\end{array}$ & $\begin{array}{l}\text { Many thanks for this comment, we } \\
\text { appreciate a lot. }\end{array}$ \\
\hline $\begin{array}{l}\text { 2. Relationship to Literature: Does the paper } \\
\text { demonstrate an adequate understanding of the } \\
\text { relevant literature in the field and cite an } \\
\text { appropriate range of literature sources? Is any } \\
\text { significant work ignored?: } \\
\text { A real paragraph devoted to the literature review } \\
\text { is missing. However, the author refer to previous } \\
\text { similar works in the paragraph devoted to the } \\
\text { theory and hypotheses. } \\
\text { However, I think that this paragraph may be } \\
\text { improved by referring to other paper that have } \\
\text { analysed the integrated reporting disclosure and } \\
\text { its determinants, such as: } \\
\text { 1) Nicolo, G., Zanellato, G., Manes-Rossi, F., \& } \\
\text { Tiron-Tudor, A. (2021). Corporate reporting } \\
\text { metamorphosis: empirical findings from state- } \\
\text { owned enterprises. Public Money \& } \\
\text { Management, 41(2), 138-147. } \\
\text { 2) Songini, L., Pistoni, A., Tettamanzi, P., Fratini, }\end{array}$ & $\begin{array}{l}\text { We thank you for this observation. } \\
\text { We have added a separate paragraph } \\
\text { providing a summary of SR and IR } \\
\text { studies and cited the suggested and } \\
\text { other literature appropriately. }\end{array}$ \\
\hline
\end{tabular}




\begin{tabular}{|l|l|}
\hline Reviewers Comments & Authors Comments \\
\hline $\begin{array}{l}\text { F., \& Minutiello, V. (2021). Integrated reporting } \\
\text { quality and BoD characteristics: an empirical } \\
\text { analysis. Journal of Management and } \\
\text { Governance, 1-42. }\end{array}$ & \\
$\begin{array}{l}\text { 3) Manes-Rossi, F., Nicolò, G., Tudor, A. T., \& } \\
\text { Zanellato, G. (2020). Drivers of integrated } \\
\text { reporting by state-owned enterprises in Europe: } \\
\text { a longitudinal analysis. Meditari Accountancy } \\
\text { Research. }\end{array}$ & \\
\hline $\begin{array}{l}\text { 3. Methodology: Is the paper's argument built on } \\
\text { an appropriate base of theory, concepts, or other } \\
\text { ideas? Has the research or equivalent intellectual } \\
\text { work on which the paper is based been well } \\
\text { designed? Are the methods employed } \\
\text { appropriate?: }\end{array}$ & \\
$\begin{array}{l}\text { The methodology is well structured and is } \\
\text { coherent to the purpose of the paper. I only } \\
\text { suggest authors better clarify why they select an } \\
\text { unweighted scoring approach. }\end{array}$ & $\begin{array}{l}\text { Thank you for this observation. } \\
\text { index is now provided. }\end{array}$ \\
\hline $\begin{array}{l}\text { 4. Results: Are results presented clearly and } \\
\text { analysed appropriately? Do the conclusions } \\
\text { adequately tie together the other elements of the } \\
\text { paper?: }\end{array}$ & \\
$\begin{array}{l}\text { Results are interesting. However, in the current } \\
\text { form, they seem a little bit disconnected from the } \\
\text { theoretical background. I suggest authors } \\
\text { improve the discussion of results by creating } \\
\text { more links with theoretical background (e.g. } \\
\text { Institutional theory, agency theory and } \\
\text { stakeholder theory) also referring to the } \\
\text { aforementioned studies. }\end{array}$ & We thank you for this comment. \\
\hline $\begin{array}{l}\text { 5. Implications for research, practice and/or } \\
\text { society: Does the paper identify clearly any } \\
\text { implications for research, practice and/or } \\
\text { society? Does the paper bridge the gap between and the relevant } \\
\text { theory and practice? How can the research be } \\
\text { used in practice (economic and commercial }\end{array}$ & \\
\hline
\end{tabular}




\begin{tabular}{|l|l|}
\hline Reviewers Comments & Authors Comments \\
\hline $\begin{array}{l}\text { impact), in teaching, to influence public policy, in } \\
\text { research (contributing to the body of } \\
\text { knowledge)? What is the impact upon society } \\
\text { (influencing public attitudes, affecting quality of } \\
\text { life)? Are these implications consistent with the } \\
\text { findings and conclusions of the paper?: }\end{array}$ & \\
$\begin{array}{l}\text { Yes, I only suggest authors add as a further } \\
\text { research strand the possibility to use a } \\
\text { disclosure index based on a qualitative/weighted } \\
\text { approach. }\end{array}$ & Thank you for the suggestion. \\
\hline $\begin{array}{l}\text { 6. Quality of Communication: Does the paper } \\
\text { clearly express its case, measured against the } \\
\text { technical language of the field and the expected } \\
\text { knowledge of the journal's readership? Has } \\
\text { attention been paid to the clarity of expression } \\
\text { and readability, such as sentence structure, } \\
\text { jargon use, acronyms, etc.: }\end{array}$ & \\
\begin{tabular}{l} 
The paper is clear and well written. \\
\hline
\end{tabular} & $\begin{array}{l}\text { Thank you for this comment, it is } \\
\text { noted. }\end{array}$ \\
\hline
\end{tabular}

We hope the revision meets the requirement and standard expected of JFRA articles and do look forward to a positive response from you soon.

Sincerely yours

Corresponding Author, on behalf of Co-Authors. 